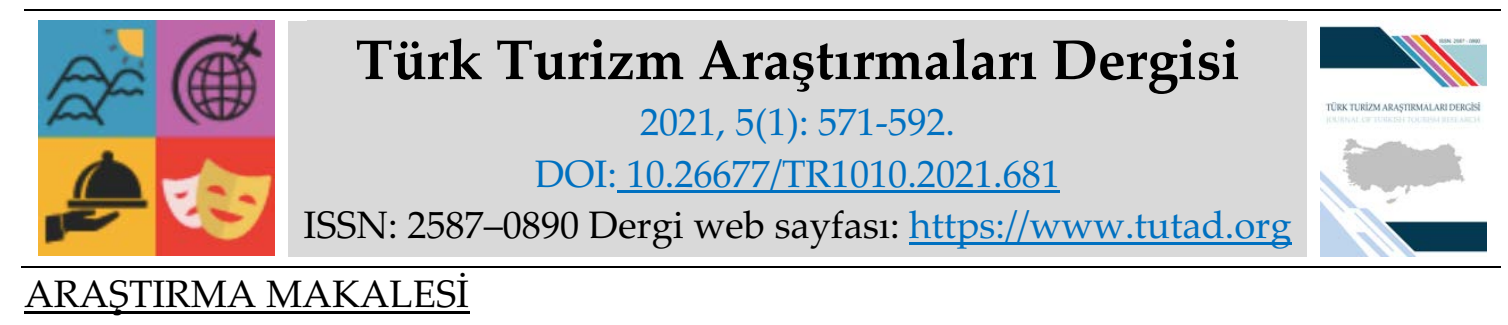

\title{
Kadın Çalışanların Otel Mutfaklarında İstihdam Edilememe Nedenleri
}

Öğretim Görevlisi, Gülcan DAĞAŞAN, Batman Üniversitesi, Hasankeyf Meslek Yüksek Okulu, Batman, e-posta: gulcan.dagasan@batman.edu.tr ORCID: https://orcid.org/0000-0003-1585-647X

\section{Öz}

Toplumsal cinsiyet rolleri açısından değerlendirildiğinde yemek yapmak ve mutfakla ilgili diğer işler kadınların görevi sayılmaktadır. Toplum tarafından kadınlara atfedilmiş bu görevlerin, özel alanlarda çoğunlukla kadınlar tarafından yerine getirildiği görülmektedir. Ancak yemek yapmak ve mutfakla ilgili diğer işler kamusal alana taşındığında yani profesyonel bir meslek/iş halini aldığında, genellikle erkekler tarafından icra edildiği gözlemlenmektedir. Literatürde yer alan araştırmalardan yola çıkılarak, keşifsel türde tasarlanan çalışmasının amacı, kadınların otellerdeki profesyonel mutfaklarda istihdam edilme/edilmeme durumlarının ve nedenlerinin araştırılmasıdır. Akdeniz Bölgesi'nde faaliyet gösteren beş yıldızlı sayfiye ve şehir otellerinde çalışan, 60 aşçbaşı ile 2017 yılı Nisan-Mayıs aylarında gerçekleştirilen ve yarı yapılandırılmış görüşme tekniğiyle toplanan nitel verilerin analizi sonucunda, otellerdeki profesyonel mutfaklarda kadın istihdamının genellikle tercih edilmediği sonucuna ulaşılmıştır. Kadınların otellerdeki profesyonel mutfaklarda istihdam edilmeme nedenleri; kadınların profesyonel mutfaklardaki işin yapısına uygun olmamasından ve profesyonel mutfak tecrübelerinin yetersizliğinden, toplumsal cinsiyet rollerine bağlı mesai ve izin sorunlarından, profesyonel mutfaklardaki erkek egemen ortamdan, kadınların karakter/ kişilik/duygusal vb. özelliklerinden, kadınlara yüklenen toplumsal cinsiyet rollerinden, kadınların henüz işe alınmadan karşılaştıkları kariyer engellerinden, kadınların fiziksel özelliklerinden ve profesyonel mutfaklarla ilgili kariyer hedeflerinin olmamasından kaynaklanan sorunlar başlıkları altında gruplandırılmıştır. Bulgular, mevcut literatürdeki çalışmaların sonuçlarından hareketle tartışılmıştır. Günümüzde, kadınların iş yaşamında karşılaştığı istihdam sorunlarını genel anlamda inceleyen çalışmalara sıkça rastlanmaktadır. Ancak spesifik olarak kadın aş̧̧ların iş yaşamında karşılaştıkları istihdam sorunlarını araştıran çalışmaların sınırlı/dolaylı olması çalışmasının özgün değerine ve kuramsal katkısına işaret etmektedir. Otel işletmelerinin üst düzey yöneticilerinin yanında özellikle insan kaynakları yöneticilerine ve aşçbaşılara, mutfaklardaki kadın istihdamı konusundaki yetersizliğin iletilmesi ve aşçıbaşılar tarafından ifade edilen temel sorunların aslında aşılabilir olduğunun altının çizilmesi; genel olarak iş yaşamında, özel olarak da mutfaklarda arzu edilen kadın erkek eşitliğine ulaşmada faydalı olacaktır. Gelecekte; şehir otellerinde, sayfiye otellerine göre neden daha az kadın istihdam edildiğinin araştırılması literatüre katkı sağlanması açısından önerilmektedir.

Anahtar Kelimeler: Toplumsal Cinsiyet, Toplumsal Cinsiyet Rolleri, Kadın İstihdamı, Kadın Aş̧̧ı, Otel Mutfakları.

Makale Gönderme Tarihi: 29.09.2020

Makale Kabul Tarihi: 04.03.2021

\section{Önerilen Atıf:}

Dağaşan, G. (2021). Kadın Çalışanların Otel Mutfaklarında İstihdam Edilememe Nedenleri, Türk Turizm Araştırmaları Dergisi, 5(1): 571-592.

(c) 2021 Türk Turizm Araştırmaları Dergisi. 


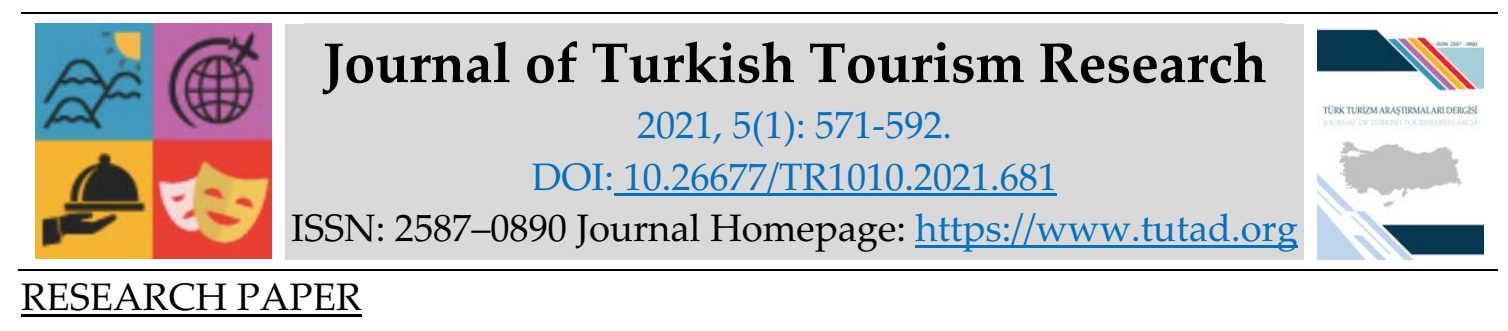

\title{
Reasons Why Women Employees Cannot Be Employed in Hotel Kitchens
}

Lecturer Gülcan DAĞAŞAN, Batman University, Hasankeyf Vocational School, Batman, e-mail: gulcan.dagasan@batman.edu.tr ORCID: https://orcid.org/0000-0003-1585-647X

\begin{abstract}
When assessed in terms of gender roles, cooking and the other tasks related to kitchen are regarded as the duty of women. It is seen that these duties attributed to women by the society are mostly performed by women in private areas. However, it is observed that when cooking and other Works which are related to the kitchen in public areas, are usually performed by men. From the researches in the literature the purpose of this, designed in an exploratory style, is to investigate the reasons why the women are/aren't employed in Professional kitchens in the hotels. As a result of the analysis of qualitative data gathered by semistructured interview technique in April-May 2017 from 60 cooks working in the five-star resort and the city hotels in the Mediterranean region, women's employment is usually not preferred in the professional kitchens in the hotels. Reasons why women are not employed in professional kitchens in the hotels are grouped under women not fit for work in professional kitchens, inadequate professional kitchen experience of women, gender roles-related work and day-off problems, male dominant environment in professional kitchens, women's character/personality/emotional and etc. features, women's gender roles, career barriers that women face before they are hired, physical characteristics of women, absence of career goals related to professional kitchens heading. Findings have been discussed with the results of studies done by different researchers on key concepts covering the thesis topic in the current literature. Today, there are many studies that examine the general employment problems women face in the work life. However, existence of the limited/indirect studies of the specific employment problems faced by female cooks in work life point to the original value and the theoretical contribution of the thesis. Notifying the inadequacy of women employment in Professional kitchens in the hotels to senior managers, human resources managers and chefs in the hotels and underlining the basic problems expressed by the chefs are in fact over table will be beneficial in reaching the desired equality (in work life in general and in the professional kitchens in particular) of men and women. In the future; to contribute to the literature, investigation of why fewer women are employed in city hotels than at resort hotels is suggested.
\end{abstract}

Keywords: Gender, Gender Roles, Women's Employment, Woman Cook, Hotel Kitchens.

Received: 29.09.2020

Accepted: 04.03.2021

\footnotetext{
Suggested Citation:

Dağaşan, G. (2021). Reasons Why Women Employees Cannot Be Employed in Hotel Kitchens, Journal of Turkish Tourism Research, 5(1): 571-592.

(C) 2021 Türk Turizm Araştırmaları Dergisi.
} 


\section{Gíriş}

Kadınlar ve erkekler biyolojik faktörler açısından farklılık göstermektedir. Literatürde kadın ve erkek arasındaki bu farklılık "cinsiyet" olarak tanımlanmaktadır (Zeybekoğlu, 2009:1). Cinsiyet, kadınlığın ve erkekliğin biyolojik yönünü ifade ederken; toplumsal cinsiyet biyolojik cinsiyete ek olarak, toplumun ve kültürün kadın ve erkek cinsiyetine yüklediği anlamları ifade etmektedir (Çınar, 2013:1). Toplumsal cinsiyet kavramının içerdiği konulardan birisi de toplumsal cinsiyet rolleridir (Yılmaz vd., 2009:777). Bireyler, doğumdan itibaren toplumun onların cinsiyetlerine yönelik beklediği toplumsal cinsiyet rolleri çerçevesinde, kız ya da oğlan çocuğu olmayı öğrenerek büyümektedir (Turan vd., 2011:168). Toplumsal cinsiyet, kadını; ev işleri, aile, çocuklarla ilgilenme gibi ikinci planda olan işlerle özdeştirirken, erkeği; evin geçimini sağlayan, evin reisi rolleriyle özdeştirmektedir (Kansu, 2015:4). Sonradan öğrenilen bu roller, kadını özel alanla (ev içi), erkeği ise kamusal alanla bütünleştirmiştir (Sezer ve Dönmez, 2016:679). Günümüzde tüm dünyada etkili olan bu roller kadını eve mahkûm ederek, onların eğitimden ve ekonomik olanaklardan erkeklerle eşit şekilde faydalanamamalarına neden olmaktadır (Turan vd., 2011:168). Kadınların ekonomik ve toplumsal açıdan ikincil konumda olmalarının bir diğer nedeni ise toplumda baskın olan ataerkil (erkek egemen) kültürdür (Kocacık ve Gökkaya, 2005:197). Ataerkil "soyda, temel olarak babayı alan ve ailede çocukları baba soyuna mal eden (topluluk), pederşahi, patriarkal” olarak tanımlanmaktadır (www.tdk.gov.tr). Ataerkil sistemde kurallar, erkekler tarafından belirlenmektedir ve kadınlardan bu sistem içinde var olabilmeleri için bu kurallara uygun davranmaları beklenmektedir. Ataerkil sistemin dayattığı bu zorunlu kurallar, bir süre sonra her iki cinsiyet tarafından da doğal olan bir durummuşçasına normalleştirilmektedir (Kalaycı ve Hayırsever, 2014:3).

Temelde ataerkil sistemi eleştiren feminizm, kadınların ataerkil sistemde değersizleştiğini savunmaktadır (Üzel, 2006:11). Radikal feminizm ise kadınların toplumdaki ikincil durumunun ataerkil sistemden kaynaklandığını vurgulamaktadır (Kan, 2012:53). Feminizm temelinde cinsiyet eşitsizliğine karşı olan, kamu ve özel alanlarda kadınların maruz kaldığı baskılara son verilmesi gerektiğini destekleyen ve ataerkil sisteme karşı durarak, kadınların sahip olması gereken hakların alınması için mücadele veren bir yaklaşımdır (Taş, 2016:163). Öte yandan liberal feminizm, erkeklerin sahip olduğu vatandaşlık haklarından kadınların da erkeklerle aynı şekilde faydalanmasını ve bu anlamda gerekli olan eşitliğin sağlanmasını talep etmektedir. Liberal feministlere göre her iki cinsiyete eşit yasaların uygulanması halinde, kadınlar ezilmeyecek ve bu sayede toplumda eşitlik sağlanabilecektir (Gökhan, 2010:32-33). Marksist feminizm kuramı ise kadınların çalışma yaşamının dışındaki özel alanlarda olmaları nedeniyle ezildiklerine işaret etmektedir (Tür ve Koyuncu 2010:14). Kadının toplumdaki yeri senelerce ev içinde (özel alan), çocuk bakımı ev işleri ile kısıtlanmıştır. Nihayet 19. yüzyılda başlayan sanayileşme hareketleriyle kadın, kamusal alanda da kendine yer bulmaya başlamış ve ücretsiz ev işçiliğinden sıyrılarak kamusal alanda, ücretli çalışma imkânına kavuşmuştur (Kuzgun ve Sevim, 2004:14-15). Sanayileşmeyle çalışma yaşamına giren kadın bu kez de cinsiyete bağlı eşit olmayan uygulamalara maruz kalmaya başlamıştır. Kadınların çalışma yaşamında maruz kaldıkları bu eşitsizlikler; eğitim imkânlarında, işe alımlarda, iş bulma ve terfi olanaklarında, sosyal haklardan yararlanmada yaşanan eşitsizlikler ile cinsel taciz olarak sıralanmaktadır (Güleç, 2015:15). Benzer sorunların otellerdeki profesyonel mutfaklarda çalışan kadınlarca da yaşanabileceği düşünülmektedir. Verilen bilgilerden hareketle keşifsel türde tasarlanan çalışmasının amacı, kadınların otellerdeki profesyonel mutfaklarda istihdam edilme/edilmeme durumlarının ve nedenlerinin araştırılmasıdır. 


\section{KAVRAMSAL ÇERÇEVE}

\section{Cinsiyet, Toplumsal Cinsiyet ve Toplumsal Cinsiyet Rolleri}

Cinsiyet, bireye atfedilen bir statü olarak kabul edilmektedir. Temelde, kadın veya erkek olarak iki farklı cinsiyet bulunmaktadır. Biyolojik olarak; kıl dağılımı, ortalama ağırlık ve uzunluk, üreme organları vb. cinsiyet farklılığını belirten özelliklerdendir. Kromozomların, hormonların ve beyin yapısının iki farklı cinsiyetten birine sahip bireyin vücudunu, kişilik özelliklerini ve davranışlarını etkileme gücü bulunmaktadır. Östrojen, progesteron, oksitosin ve seratonin hormonları kadın davranışlarını ve kişilik özelliklerini etkilerken; testosteron hormonu erkek kişilik özelliklerini ve davranışlarını etkilemektedir (Samanlı, 2014:30). Cinsiyet kavramı, kadın veya erkek olmanın biyolojik olarak tanımlanmasını ifade etmektedir. Cinsiyet, demografik bir kategoridir. Kadın veya erkek olmaya toplumun ve kültürün yüklediği anlamları ve beklentileri ifade eden toplumsal cinsiyet kavramı ise genellikle bireyin biyolojik yapısıyla ilişkili psikolojik özelliklerini de içermektedir. Toplumsal cinsiyet, bireye kadınsı veya erkeksi olarak karakter kazandıran psiko-sosyal özelliklerdir (Dökmen, 2015:20).

Toplumsal cinsiyet, kavram olarak ilk defa 1950'lerin ortalarında psikoloji alanında kişilik patolojilerinin tedavisi alanında kullanılmıştır. Bu kapsamda toplumsal cinsiyet, "kimlik" olarak kavramlaştırılmıştır. "Toplumsal cinsiyet kimliği" ise bir kişinin kadın ya da erkek olduğuna dair öz algisı olarak tanımlanmıştır (Cengiz, 2013:3). Toplumsal cinsiyet terimini sosyolojiye kazandıran AnnOakley'e (1972) göre, "cinsiyet - sex" biyolojik anlamda kadın-erkek ayrımını anlatırken; "toplumsal cinsiyet - gender" kadınlığa ve erkekliğe paralel, toplumsal bakımdan eşitsiz bölünmeye gönderme yapmaktadır (Üzel, 2006:66-67). Bu kavramı ilk kullanan feminist akademisyen AnnOakley; toplumsal cinsiyetin bir kültür meselesi olduğuna; kadınların ve erkeklerin sosyal anlamda "dişil" ve "eril" olarak sınıflandırıldığına işaret etmektedir (Bhasin, 2003: 9). Toplumsal cinsiyet kavramı, toplum tarafından dikte edilen kadın veya erkek olma hali ile bağdaştırılmış sosyokültürel kuralları kapsamaktadır. Her kültürde kabul edilen cinsiyet kimlikleri bulunmaktadır ve bir toplumun kültüründeki sosyal kurallar; kadınların veya erkeklerin görünüşlerinin, davranışlarının ve dış dünya ile ilişkilerinin nasıl olması gerektiğini göstermektedir (Yllmaz, 2007:144). Toplumsal cinsiyet ile birlikte toplumda toplumsal cinsiyet rolleri oluşmuştur. Toplumsal cinsiyet rolleri, toplumsal cinsiyet kavramının şemsiyesi altında yer almaktadır ve bireyin yaşamını sürdürdüğü toplumun kültüründe, bir kadına ya da erkeğe nasıl davranacağına, kadının ya da erkeğin neyi düşünüp, nasıl hareket edeceğine yönelik beklentileri ortaya koymaktadır (Yılmaz vd., 2009:777). Toplumsal roller kadının ve erkeğin yaşamı boyunca sergilediği ve sergileyeceği davranışlar üzerinde oldukça egemendir. Kadınlar; yuva yapıcı, ev kurucu, çocuk bakıcı; erkekler ise ekmek kazanıcı olarak cinsiyete dayalı bir iş bölümü sürdürmektedir. Toplumun bireye atfettiği bu roller ona çocukluktan itibaren öğretilmektedir. Küçük kızlar eş ve anne olarak yetişkin rollerine hazırlanırken, genellikle yemek yapma ile ilgili oyuncaklarla ve bebeklerle oynamaktadır (Sankır, 2010:5). Toplumsal cinsiyet rolleri, bireylerin yaşayarak öğrendikleri davranışları bazı durumlarda uygulamasıdır. Sonradan öğrenilen ve kadın ile erkek arasındaki farkı oluşturan bu roller, kadını; anne ve ev içi işçi olarak nitelendirirken, erkeği kamusal alana uygun görmektedir. Kadınlar kendi rolleri ile bütünleşerek bu rollere uygun hareket etmektedir. Kadınların özel alanla bütünleşmesi, onların kamusal alanlardan uzaklaşmasına neden olmaktadır (Sezer ve Dönmez, 2016:679).

Özel alan ve kamusal alan ayrımı Antik Yunan dönemine kadar uzanmaktadır. Antik Yunan, demokrasinin beşiği olarak kabul görmektedir ancak bu demokrasi sisteminde, kadınlar ve köleler kabul görmemektedir. Antik Yunan döneminde, özgür kadınların vatandaş sayılmadığ 1 ve kadınların, kadın oldukları için kamusal alana girmeye uygun görülmediği varsayımı üzerine 
kurulu bir demokrasi sisteminden bahsedilmektedir. Kamusal alan / özel alan ayrımı Antik Yunan düşüncesinde, "polis - kamusal alan" ile "oikos - hane" kavramlarından türetilmektedir. Polis; erkeklerin yönetim alanı sayılırken, oikos; kadınların ve çocukların yeri, ev içi alan olarak görülmektedir (Ersöz, 2015:83-84). Erkeklere, doğaya egemen olma ve yaratma işlevi atfedilmekte; kadınlara ise bakımla ilgili önemsiz işler verilmektedir. Fiziksel güçsüzlük önyargısı; kadının, özel mülkiyet ve çocuklar gibi korunması gereken veya korunmaya ihtiyacı olan şeyler arasına girmesine ve belli toplumlarda belli tür işleri yapmasına (kadın işleri) dayanak oluşturmaktadır (Buz, 2009:56).

Toplumlardaki ataerkil yapı özel alan / kamusal alan ayrımlaşmasında da anahtar rol üstlenmektedir. Kadınların kamusal alandan mahrum bırakılmaları, doğrudan ataerkil ideolojinin doğa - kültür ayrımından kaynaklanmaktadır. Kadın bedeni, doğurganlık özellikleri nedeniyle, doğa ile özdeşleşmektedir (Ersöz, 2015:88). Kadının anneliği, birçok toplumda onu eve (özel alana) bağlamaktadır (Kaypak, 2014:346). Buna karşılık, erkeklerin, uygarlığı ve kültürü temsil ettiği kabul edilmektedir. Buradan hareketle, erkeklerin işi kültür ve uygarlık yaratmak, kamusal alanda otorite kullanmak ve yönetmek iken; kadınların işi ise ev ve aile içinde kalıp çocuk doğurmak, ev ve ev işleri ile ilgilenmek olarak belirlenmiştir (Ersöz, 2015:88). Özellikle feminist düşünürler, özel alan ve kamusal alan ayrımının kadınları birçok haktan mahrum bıraktığını savunmaktadır (Türkoğlu, 2015:6).

\section{Otel İşletmelerindeki Profesyonel Mutfaklarda Kadının Karşılaştığı Eşitsizlikler ve Yaşadığı Zorluklar}

Mutfaklarda kadınların karşılaştıkları sorunlar ve zorluklar ile ilgili çoğu dolaylı/sınırlı sayıda çalışmaya rastlanmaktadır. Bu araştırmalardan elde edilen sonuçlar aşağıda özetlenmektedir. Birdir, Derinalp ve Çanakçı'nın (2013), mutfak çalışanlarının sorunlarına yönelik yaptıkları çalışmada; 20 otelden, 73 iş görene anket uygulanmıştır. Araştırmaya katılmaya kabul eden örneklem grubunun \%80'i erkek, \%20'si kadındır. Giritlioğlu'nun (2010) araştırmasında ise katılımcıların \%89'u erkeklerden, \%11'i kadınlardan oluşmaktadır. Birdir ve Kılıçhan'ın (2013) yine mutfak çalışanlarıyla ilgili çalışmalarına \%93 erkek, \%7 kadın dâhil olmuştur. Mutfak çalışanlarının cinsiyetlerine dair özetlenen istatistikler, profesyonel mutfakların cinsiyet ayrımcllı̆ının yaşandığı, erkek egemen alanlar olduğunu göstermektedir. Birdir, Derinalp ve Çanakçı (2013), mutfak çalışanlarının, cinsiyet değişkenine göre yaşadığı sorunların başında, mutfaklarda eşit işe eşit ücret uygulanmamasını rapor etmiştir. Araştırmada ayrıca, erkeklerden daha düşük ücretlendirilen kadınların, ücret adaletsizliği nedeniyle iş performanslarının düştüğünün de altı çizilmiştir. Bir başka bulgu, kadın çalışanların erkeklere göre daha niteliksiz işlere uygun görüldüğü ve kıdem olarak yükselmelerinin engellendiği şeklindedir.

Sezer ve Dönmez'in (2016), profesyonel kadın aşçların, kadın kimliğiyle profesyonel mutfaklardaki çalışma yaşamına bakış açlarının tespitine yönelik yaptıkları araştırmada; yaşadıkları zorlukların; işin fiziki güç gerektirmesi, küfürlü konuşmalara maruz kalma, erkeksileşme, erkeklerin niceliksel üstünlüğü, uyum sağlayamayanların erkeklerce dışlanması, işin yorucu/yoğun/zor olması, erkeklere kendini ispatlama zorunluluğu, kişisel bakım (oje, fön) yapamama, diğer kadınlara özenme, vücuda sinen yemek/yağ kokusu, tatillerin belirsizliği, sosyal yaşamdan uzaklaşma ve çalışma saatlerinin belirsizliği şeklinde sıralandığı sonucuna ulaşılmıştır. Profesyonel kadın aş̧̧ların, mutfaklarda yaşadıkları zorluklar üç başlık altında temalaştırılmıştır. Bunlar; erkek egemen ortamdan kaynaklanan zorluklar, işin yapısından kaynaklanan zorluklar ve bireyin kendisinden kaynaklanan zorluklardır (Sezer ve Dönmez, 2016). Araştırma bulguları \%48'lik bir oranla, erkek egemen ortamların sorunun kaynağını oluşturduğunu göstermektedir. Toplumsal cinsiyet rolleri açısından "kadın işi" olarak 
nitelendirilen yemek yapma, profesyonel alanlarda "erkek işi" ne dönüşmekte ve mutfaklar cinsiyet ayrımcılığının yaşandığı alanlar haline gelmektedir.

Çelik ve Şahingöz' ün (2018), iş yaşamındaki cinsiyet ayrımcılı̆̆ında kadın aşçılara yönelik yaptığı çalışmasında; kadınların işe alınma, ücretlendirme ve terfi konularında cinsiyete yönelik ayrımcı uygulamalara maruz kaldıkları sonucuna varılmıştır. Ayrıca kadın aşçların cinsiyetleri nedeniyle basmakalıp önyargılar ile de karşı karşıya kaldıkları belirtilmiştir (Çelik ve Şahingöz, 2018:379-380). Keskin ve Kızılırmak'ın (2020), mutfak departmanında çalışan kadınların cinsiyet ayrımcılığına yönelik çalışmasında; mutfaklarda kadınların arka planlarda çalıştırıldıkları, küfürlü konuşmalara, cinsiyet eşitsizliği, ücret eşitsizliği, mobbing, sözlü ve fiziki tacize maruz kaldıkları belirtilmiştir (Keskin ve Kızılırmak, 2020:1225).

Kadınların profesyonel mutfaklarda yaşadıkları zorluklar ile ilgili olarak sınırlı sayıda çalışmaya rastlanmıştır. Yapılan çalışmaların sonucunda kadınlar profesyonel mutfaklarda cinsiyet eşitsizliği, cinsiyet ayrımcılığı, aynı pozisyonda olunmasına rağmen uygulanan ücret eşitsizliği, mobbing, sözlü ve fiziksel tacize maruz kaldıkları görülmektedir.

\section{YÖNTEM}

Çalışma kadınların otellerdeki profesyonel mutfaklarda istihdam edilme/edilmeme durumlarının ve nedenlerinin araştııılması amaçlanmaktadır. Konu ile ilgili, çoğu dolaylı, sınırlı çalışmaya rastlanılması nedeniyle araştırma keşifsel türde tasarlanmıştır. Bu amaçla, yarı yapılandırılmış görüşme tekniğinden yararlanılmıştır. Yapılan görüşmelerde katılımcılara yöneltilen araştırma soruları, Türkiye İstatistik Kurumu - TUIKK internet sitesinde, Toplumsal Yapı ve Cinsiyet İstatistikleri başlı̆̆ı altında yayınlanmış işgücü istatistiklerine dayanarak oluşturulmuştur (www.tuik.gov.tr). Araştırma soruları aşağıda maddeler halinde siralanmaktadir.

1. Çalıştığınız otelin mutfak bölümünde toplam kaç kişi istihdam edilmektedir?

2. Çalıştığınız otelin mutfak bölümünde istihdam edilenlerin kadın/erkek oranı nedir?

3. Çalıştığınız otelin mutfak bölümünde istihdam edilen kadın var ise mutfağın hangi bölümünde çalıştırılmaktadır?

4. Çalıştı̆̆ınız otelin mutfak bölümünde istihdam edilen kadınların az/çok sayıda olmasının nedenleri nelerdir?

Araştırmada örnekleme yöntemi olarak, amaçlı örnekleme yöntemlerinden biri olan kartopu örnekleme yöntemi tercih edilmiştir. Araştırma konusu ile ilgili çoğu dolaylı, sınırlı çalışma olması nedeniyle örneklem büyüklüğü önceden tahmin edilemediği için araştırma sorularının cevabı olabilecek kavramların ve süreçlerin tekrar ettiği aşamaya kadar veri toplama işlemi devam ettirilmiştir. Veri toplama işlemi, 60 aşçıbaşıdan oluşan örnek büyüklüğüne ulaşıldığında yeterli kabul edilmiştir ve sonlandırılmıştır (Yıldırım ve Şimşek, 2008:115). Görüşmeler, 2017 yılı Nisan ve Mayıs aylarında, Akdeniz Bölgesi'nde faaliyet gösteren beş yıldızlı sayfiye (30 aş̧̧ıaşı) ve şehir otellerinde (30 aşçıbaşı) çalışan, 60 aşçıbaşı ile gerçekleştirilmiştir. Yarı yapılandırılmış görüşme yoluyla, 60 aşçbaşına yöneltilen araştırma sorularına alınan cevaplar aracılığıyla elde edilen veriler, araştırmacı tarafından olduğu gibi bilgisayar ortamına aktarılmış, düzenlenmiş ve içerik analizine tabi tutulmuştur. İçerik analizi, Yıldırım ve Şimşek (2008:227-252) tarafından ifade edilen ayrıntılara dikkat edilerek yapılmıştır. Görüşmeler, aşçıbaşıların müsait olduğu gün ve saatlere göre, onların tercih ettikleri yerlerde (mutfak veya restoran) yapılmıştır. Araştırmaya katılmayı kabul eden 60 aşçıbaşıdan 6'sı ses kaydı alınmasını kabul etmiş, kalan 54'ünün cevapları ise araştırmacı tarafından not edilmiştir. Ses kaydı vermeyi kabul etmeyen aşçıbaşıların 
cevaplarının olabildiğince ayrıntılı not edilmesi için özen gösterilmiştir. Verilen cevaplar, kısa kelimeler halinde değil, katılımcıların kullandığı cümleler olabildiğince yazılarak kayda geçirilmiştir. Yarı yapılandırılmış görüşme yoluyla, 60 aşçıbaşına yöneltilen araştırma sorularına alınan cevaplar aracılığıyla elde edilen veriler, araştırmacı tarafından olduğu gibi bilgisayar ortamına aktarılmış, düzenlenmiş ve içerik analizine tabi tutulmuştur. İçerik analizi, Yıldırım ve Şimşek (2008) tarafından ifade edilen ayrıntılara dikkat edilerek yapılmıştır. İçerik analizi ile kod ve temaların oluşturulması aşamaları, araştırmacının dışında üç farklı öğretim üyesi (araştırma sorularının uygunluğunu kontrol edenler) tarafından da tekrarlanmıştır. Ortaya çıkan benzerlikler ve farklılıklar üzerine yapılan değerlendirmeler neticesinde kod ve temalara son hali verilmiştir.

\section{BULGULAR}

Bulgulara ilişkin yürütülen tartışma, literatürde doğrudan konu ile ilgili görece sınırlı sayıda araştırmaya rastlandığı için toplumsal cinsiyet, toplumsal cinsiyet rolleri, kamusal alan/özel alan, ataerkil sistem, feminizm ve kadınların çalışma hayatında karşılaştıkları zorluklar kapsamında yürütülmektedir.

Araştırma kapsamında cevabı aranan ilk üç araştırma sorusu aşağıdaki gibidir.

1.Çalıştı̆̆ınız otelin mutfak bölümünde toplam kaç kişi istihdam edilmektedir?

2.Çalıştığınız otelin mutfak bölümünde istihdam edilenlerin kadın/erkek oranı nedir?

3.Çalıştığınız otelin mutfak bölümünde istihdam edilen kadın var ise mutfağın hangi bölümünde çalıştırılmaktadır?

Araştırmaya katılmayı kabul eden 60 aşçıbaşıdan, kendilerine yöneltilen ilk üç araştırma sorusuna alınan cevaplar Tablo 1'te özetlenmektedir.

Tablo 1 incelendiğinde otellerdeki profesyonel mutfaklarda çalışan ve araştırmaya katılmayı kabul eden 60 aşçıbaşının tamamının (\%100) “erkek" olduğu görülmektedir. Pekerşen'in (2015) Türkiye genelindeki aşçları kapsayan doktora tezindeki tanımlayıcı istatistiklerde, örnekleme dâhil olan 449 aşçının sadece 54'ünün (\%12) kadın olduğu görülmektedir. Pekerşen ile yapılan telefon görüşmesinde 54 kadın aşçının hiçbirinin aş̧̧ıbaşı olmadığı öğrenilmiştir. Bu bağlamda bulguların birbirini desteklediği ve otellerdeki profesyonel mutfakların yönetiminin, erkek aşçıbaşıların elinde olduğu söylenebilir. Kadınlar, toplumsal önyargılara rağmen çalışma yaşamında yer edinmeye başlamıştır. Ancak ne kadar gayretli olsalar da kadınların, çalıştıkları pozisyonlarda ilerleyerek yönetim kademelerinde görev almalarının önünde yine çeşitli engeller bulunmaktadır. Bu engeller literatürde; cam tavan, cam duvar, cam uçurum, cam asansör, cam labirent, ikinci cam tavan, bambu perde, yapışkan zemin vb. kavramlarla açıklanmaktadır (Keskin, 2016: 50-51). Birinci araştırma sorusu ile araştırmaya dâhil edilen otellerdeki profesyonel mutfaklarda istihdam edilen iş gören sayısı anlaşılmaya çalışılmaktadır. Tablo 1 'te özetlenen bulgularda en yüksek istihdamın, 90 iş gören ile 8. otelde; en düşük istihdamın ise 4 iş gören ile 55. otelde olduğu anlaşılmaktadır. İş gören sayılarının, otellerin profesyonel mutfaklarındaki iş hacmi ile ilgili de bir fikir oluşturabileceği söylenebilir. 
Tablo 1: Otellerdeki Profesyonel Mutfaklarda Çalışan İş görenlerin Cinsiyete Göre Sayısal Dağılımı ve Kadınların İstihdam Edildiği Mutfak Bölümleri

\begin{tabular}{|c|c|c|c|c|c|c|c|c|}
\hline  & 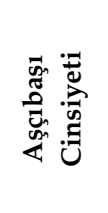 & 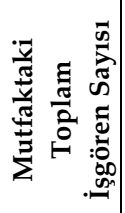 & 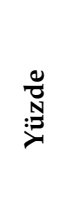 & 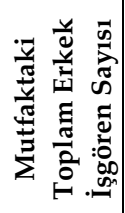 & $\begin{array}{l}\stackrel{\overbrace{}}{N} \\
:\end{array}$ & 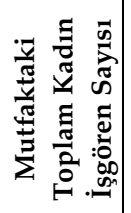 &  & 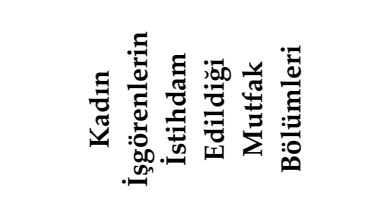 \\
\hline 1 & Erkek & 64 & 100 & 64 & 100 & 0 & 0 & Yok \\
\hline 2 & Erkek & 64 & 100 & 62 & 97 & 2 & 3 & Ön yıkama, kahvaltı \\
\hline 3 & Erkek & 25 & 100 & 22 & 88 & 3 & 12 & Kahvaltı, soğuk \\
\hline 4 & Erkek & 64 & 100 & 62 & 97 & 3 & 3 & $\begin{array}{c}\text { Ön yıkama, kahvaltı, personel } \\
\text { aşçıs }\end{array}$ \\
\hline 5 & Erkek & 64 & 100 & 54 & 84 & 10 & 16 & Kahvaltı, soğuk \\
\hline 6 & Erkek & 70 & 100 & 58 & 83 & 12 & 17 & Kahvaltı, soğuk, pastane \\
\hline 7 & Erkek & 75 & 100 & 68 & 91 & 7 & 9 & Kahvaltı, soğuk, pastane \\
\hline 8 & Erkek & 90 & 100 & 75 & 83 & 15 & 17 & Her bölümde dönüşümlü \\
\hline 9 & Erkek & 69 & 100 & 62 & 90 & 7 & 10 & Kahvaltı, soğuk \\
\hline 10 & Erkek & 27 & 100 & 25 & 93 & 2 & 17 & Kahvaltı \\
\hline 11 & Erkek & 85 & 100 & 69 & 81 & 16 & 19 & Kahvaltı, soğuk, pastane \\
\hline 12 & Erkek & 72 & 100 & 63 & 88 & 9 & 12 & Ön yıkama, kahvaltı, pastane \\
\hline 13 & Erkek & 78 & 100 & 65 & 83 & 13 & 17 & Kahvaltı, pastane, sıcak \\
\hline 14 & Erkek & 73 & 100 & 62 & 85 & 11 & 15 & Her bölümde dönüşümlü \\
\hline 15 & Erkek & 82 & 100 & 66 & 80 & 16 & 20 & Her bölümde dönüşümlü \\
\hline 16 & Erkek & 70 & 100 & 62 & 89 & 8 & 11 & Kahvaltı, soğuk \\
\hline 17 & Erkek & 85 & 100 & 70 & 82 & 15 & 18 & Kahvaltı, pastane, sıcak \\
\hline 18 & Erkek & 76 & 100 & 61 & 80 & 15 & 20 & Kahvaltı, pastane \\
\hline 19 & Erkek & 83 & 100 & 71 & 86 & 12 & 14 & Kahvaltı, soğuk, pastane \\
\hline 20 & Erkek & 77 & 100 & 63 & 82 & 14 & 18 & Her bölümde dönüşümlü \\
\hline 21 & Erkek & 48 & 100 & 40 & 83 & 8 & 17 & Kahvaltı, pastane \\
\hline 22 & Erkek & 28 & 100 & 26 & 93 & 2 & 7 & Kahvaltı \\
\hline 23 & Erkek & 71 & 100 & 63 & 89 & 8 & 11 & Kahvaltı, soğuk, pastane \\
\hline 24 & Erkek & 31 & 100 & 28 & 90 & 3 & 10 & Kahvaltı \\
\hline 25 & Erkek & 58 & 100 & 53 & 91 & 5 & 9 & Soğuk, pastane \\
\hline 26 & Erkek & 63 & 100 & 59 & 93 & 4 & 7 & Pastane \\
\hline 27 & Erkek & 71 & 100 & 63 & 89 & 8 & 11 & Soğuk, pastane \\
\hline 28 & Erkek & 17 & 100 & 16 & 94 & 1 & 6 & Her bölümde dönüşümlü \\
\hline 29 & Erkek & 73 & 100 & 60 & 82 & 13 & 18 & Kahvaltı, soğuk, pastane \\
\hline 30 & Erkek & 62 & 100 & 57 & 92 & 5 & 8 & Kahvaltı, pastane \\
\hline 31 & Erkek & 22 & 100 & 18 & 82 & 4 & 18 & Her bölümde dönüşümlü \\
\hline 32 & Erkek & 13 & 100 & 12 & 92 & 1 & 8 & Personel aşçısı \\
\hline 33 & Erkek & 7 & 100 & 6 & 86 & 1 & 14 & Kahvaltı \\
\hline 34 & Erkek & 9 & 100 & 8 & 89 & 1 & 11 & Sicak \\
\hline 35 & Erkek & 29 & 100 & 27 & 93 & 2 & 7 & Kahvaltı \\
\hline 36 & Erkek & 23 & 100 & 22 & 96 & 1 & 4 & Kahvaltı \\
\hline 37 & Erkek & 7 & 100 & 6 & 88 & 1 & 12 & Kahvaltı \\
\hline 38 & Erkek & 5 & 100 & 5 & 100 & 0 & 0 & Yok \\
\hline 39 & Erkek & 6 & 100 & 6 & 100 & 0 & 0 & Yok \\
\hline 40 & Erkek & 30 & 100 & 26 & 87 & 4 & 13 & Kahvaltı, sıcak \\
\hline 41 & Erkek & 9 & 100 & 9 & 100 & 0 & 0 & Yok \\
\hline 42 & Erkek & 8 & 100 & 7 & 88 & 1 & 12 & Kahvaltı \\
\hline 43 & Erkek & 21 & 100 & 21 & 100 & 0 & 0 & Yok \\
\hline 44 & Erkek & 16 & 100 & 14 & 88 & 2 & 12 & Her bölümde dönüşümlü \\
\hline 45 & Erkek & 9 & 100 & 8 & 89 & 1 & 11 & Kahvaltı \\
\hline 46 & Erkek & 14 & 100 & 14 & 100 & 0 & 0 & Yok \\
\hline 47 & Erkek & 40 & 100 & 40 & 100 & 0 & 0 & Yok \\
\hline 48 & Erkek & 17 & 100 & 15 & 88 & 2 & 12 & Kahvaltı, pastane \\
\hline 49 & Erkek & 21 & 100 & 19 & 90 & 2 & 10 & Kahvaltı, soğuk \\
\hline 50 & Erkek & 19 & 100 & 18 & 95 & 1 & 5 & Kahvaltı \\
\hline
\end{tabular}




\begin{tabular}{|l|c|c|c|c|c|c|c|c|}
\hline 51 & Erkek & 10 & 100 & 10 & 100 & 0 & 0 & Yok \\
\hline 52 & Erkek & 18 & 100 & 15 & 83 & 3 & 17 & Her bölümde dönüşümlü \\
\hline 53 & Erkek & 6 & 100 & 6 & 100 & 0 & 0 & Yok \\
\hline 54 & Erkek & 14 & 100 & 12 & 86 & 2 & 14 & Her bölümde dönüşümlü \\
\hline 55 & Erkek & 4 & 100 & 4 & 100 & 0 & 0 & Yok \\
\hline 56 & Erkek & 13 & 100 & 11 & 85 & 2 & 15 & Kahvaltı, soğuk \\
\hline 57 & Erkek & 6 & 100 & 5 & 83 & 1 & 17 & Her bölümde dönüşümlü \\
\hline 58 & Erkek & 11 & 100 & 9 & 81 & 2 & 19 & Kahvaltı \\
\hline 59 & Erkek & 7 & 100 & 7 & 100 & 0 & 0 & Yok \\
\hline 60 & Erkek & 15 & 100 & 13 & 87 & 2 & 13 & Her bölümde dönüşümlü \\
\hline
\end{tabular}

Tablo 1'de otellerdeki profesyonel mutfaklarda çalışan kadın ve erkek iş gören sayıları ve yüzdeleri belirtilmektedir. Bu bulgular, "çalıştığınız otelin mutfak bölümünde istihdam edilenlerin kadın/erkek oranı nedir" şeklinde formüle edilen ikinci araştırma sorusunun cevabını vermektedir. Mutfak çalışanlarının tamamının (\%100) erkek iş görenlerden oluştuğu mutfaklar; 1., 38., 39., 41., 43., 46., 47., 51., 53., 55. ve 59. otellere aittir. Bunlar arasinda 1 numaralı otel dışındakiler şehir otelleridir. Dolayısıyla şehir otellerinin profesyonel mutfaklarında tamamen erkek egemen iş gören popülasyonu, sayfiye otellerine göre daha sık görülmektedir denilebilir. Şehir otellerindeki profesyonel mutfaklarda çalışan toplam iş görenlerin \%8'inin kadın olması (sayfiye otellerinde bu oran \%13) bu bulguyu desteklemektedir. Tablo 1'de özetlenen bulgular aracılığıyla son olarak, üçüncü araştırma sorusu cevaplanmaya çalışılacaktır. Nitekim kadın istihdamının olduğu profesyonel mutfaklarda, kadınların hangi bölümlerde çalıştırıldıklarının önemli sonuçlara işaret ettiği düşünülmektedir. Kadınlar, otellerdeki profesyonel mutfaklarda; en çok "kahvaltı" bölümünde (tekrar sayısı 33) çalıştırılmaktadır. En az çalıştırılan bölüm gibi görünen ön yıkama (tekrar sayısı 3) ve personel aşçlığı (tekrar sayısı 2) aslında birer mutfak bölümü değil, mutfakta yürütülen işlerden ikisidir. Dolayısıyla kadınların en az çalıştırıldıkları mutfak bölümü "sıcak" (tekrar sayısı 4) olarak rapor edilebilir. Pastane (tekrar sayısı 16) ve soğuk (tekrar sayısı 14) bölümü ise kahvaltı bölümünü izlemektedir. Bununla birlikte her bölümde dönüşümlü (tekrar sayısı 11) çalıştırılan kadınlar da bulunmaktadır. Görüşmelerde aşçıbaşılar "hangi bölümde ihtiyaç olursa kadınların, destek iş gören olarak, o bölümlere yardım ettiklerini" ifade etmişlerdir. Dördüncü araştırma sorusuna verilen cevaplar ise içerik analizinin özetlendiği kod (Tablo 2) ve tema tablosunda (Tablo 3) gösterilmektedir.

Araştırmaya katılmayı kabul eden 60 aşçıbaşının, otellerdeki profesyonel mutfaklarda az sayıda kadın istihdam edilmesinin nedenleri Tablo 2'te özetlenmektedir. Aşçıbaşılar konu ile ilgili toplam 42 kod üzerinde yoğunlaşmaktadır. En çok tekrar edilen kodlar "kadınların profesyonel mutfak deneyimlerinin az olması/işi bilmemeleri" (41 tekrar, \%6,2), "kadınların profesyonel mutfaklardaki ağır mutfak ekipmanlarını kaldıramamaları/fiziksel anlamda zayıf olmaları" (41 tekrar, \%6,2), "kadınların profesyonel mutfaklardaki yoğun / hızlı / zor / yorucu / stresli çalışma temposuna dirençli/dayanıklı olamamaları" (37 tekrar, \%5,6), "kadınların profesyonel mutfaklardaki uzun çalışma saatlerine dirençli/dayanıklı olamamaları" (36 tekrar, \%5,4) ve "kadınların profesyonel mutfaklardaki her işi (ağır ve zahmetli işler) yapamamaları" (34 tekrar, $\% 5,1)$ şeklinde sıralanmaktadır. En az tekrar edilen kodlar ise "kadınların profesyonel mutfaklarda sakar olmaları (bir şeyleri kırıp dökmeleri)" (3 tekrar, \%0,4), "kadınların talepleri yerine getirilmediğinde surat/naz yapmaları" (3 tekrar, \%0,4), "kadınların profesyonel mutfaklarda özgüvenli olmamaları" (2 tekrar, \%0,3), "kadınların çabuk hasta olmaları ve hastayken çalışamamaları" (2 tekrar, \%0,3) ve "kadınların profesyonel mutfaklardaki sıcaklığa dirençli/dayanıklı olamamaları" (1 tekrar, \%0,2) olarak sıralamanın en sonunda yer almaktadır. 
Tablo 2: Erkek Aşçıbaşıların Mutfakta Kadınlarla Birlikte Çalışmaya Yönelik Olumsuz Düşüncelerine Dair İçerik Analizi İfade Kodları ve Açılımları

\begin{tabular}{|c|c|c|c|}
\hline İfade Kodu & İfade Açılımı & $\Sigma$ & $\%$ \\
\hline 1. İfade & Kadınların profesyonel mutfak deneyimlerinin az olması/işi bilmemeleri & 41 & 6,2 \\
\hline 2. İfade & $\begin{array}{l}\text { Kadınların profesyonel mutfaklardaki ağır mutfak ekipmanlarını kaldıramamaları/fiziksel anlamda zayıf } \\
\text { olmaları }\end{array}$ & 41 & 6,2 \\
\hline 3. İfade & $\begin{array}{l}\text { Kadınların profesyonel mutfaklardaki yoğun/hızlı/zor/yorucu/stresli çalışma temposuna dirençli/dayanıklı } \\
\text { olamamaları }\end{array}$ & 37 & 5,6 \\
\hline 4. İfade & Kadınların profesyonel mutfaklardaki uzun çalışma saatlerine dirençli/dayanıklı olamamaları & 36 & 5,4 \\
\hline 5. İfade & Kadınların profesyonel mutfaklardaki her işi (ağır ve zahmetli işler) yapamamaları & 34 & 5,1 \\
\hline 6. İfade & Kadınların fazla mesai yapmak istememeleri & 33 & 4,9 \\
\hline 7. İfade & $\begin{array}{l}\text { Kadınların çeşitli bahanelerle (çocuğum/kocam hasta/misafir gelecek/çocuğu okuldan almam gerekli/bakıcım } \\
\text { izinli vb.) sürekli izin istemeleri/işe gelmemeleri }\end{array}$ & 33 & 4,9 \\
\hline 8. İfade & $\begin{array}{l}\text { Kadınların çeşitli nedenlerle (evlenme/gebelik/çocuk sahibi olma/eşin veya ebeveynlerin çalışmalarına izin } \\
\text { vermemesi vb.) işi bırakmaları }\end{array}$ & 26 & 3,9 \\
\hline 9. İfade & Kadınların profesyonel mutfaklarda çıkan krizleri iyi yönetememeleri & 24 & 3,6 \\
\hline 10. İfade & $\begin{array}{l}\text { Kadınların belirli saatlerde evde olmaları gerektiğinden profesyonel mutfaklardaki mesai saatlerine/vardiya } \\
\text { sistemine uyamamaları }\end{array}$ & 23 & 3,5 \\
\hline 11. İfade & $\begin{array}{l}\text { Profesyonel mutfak çalışanlarının aşçıbaşının kurduğu ekipten oluşması ve ekip kurulurken kadınların } \\
\text { tercih edilmemesi }\end{array}$ & 23 & 3,5 \\
\hline 12. İfade & Kadınların profesyonel mutfak ortamına çabuk/kolay uyum sağlayamamaları/yabancılık çekmeleri & 22 & 3,3 \\
\hline 13. İfade & Toplumsal/kültürel vb. anlamda profesyonel mutfakların kadın istihdamına uygun olmaması & 20 & 3,0 \\
\hline 14. İfade & Kadınların çok çabuk alınmaları/bozulmaları/ağlamaları/küsmeleri & 19 & 2,9 \\
\hline 15. İfade & Kadınların profesyonel mutfaklardaki işleyişe uyum sağlayamayacakları için tercih sebebi olmamaları & 18 & 2,7 \\
\hline 16. İfade & Kadınların profesyonel mutfaklarda girişken olamamaları/pasifize edilmeleri & 16 & 2,4 \\
\hline 17. İfade & $\begin{array}{l}\text { Kadınların evlerinde de sorumlulukları olduğu için sürekli yorgun olmaları ve performanslarının } \\
\text { düşmesi/çabuk yorulmaları }\end{array}$ & 16 & 2,4 \\
\hline 18. İfade & Kadınların profesyonel mutfaklarda karar verme/inisiyatif kullanma konusunda pasif olmaları & 15 & 2,3 \\
\hline 19. İfade & $\begin{array}{l}\text { Kadınların profesyonel mutfaklarda çalışan erkeklerle rahat konuşamamaları/iletişim kurarken güçlük } \\
\text { yaşamaları }\end{array}$ & 15 & 2,3 \\
\hline 20. İfade & Kadınların duygusal olarak çabuk etkilenmeleri ve bunu işe yansıtmaları & 15 & 2,3 \\
\hline 21. İfade & $\begin{array}{l}\text { Kadınların evlenmesi/çocuk sahibi olması/ eşin veya ebeveynlerin çalışmalarına izin vermemesi gibi } \\
\text { nedenlerle mesleğe dair bir gelecek planlarının olmaması }\end{array}$ & 14 & 2,1 \\
\hline 22. İfade & Kadınların profesyonel mutfaklardaki işin zorluğu/yoruculuğu konusunda sürekli şikâyet etmeleri & 14 & 2,1 \\
\hline 23. İfade & Kadınlara profesyonel mutfaklardaki işlerin güvenle (göz arkada kalmadan) teslim edilememesi & 12 & 1,8 \\
\hline 24. İfade & Kadınların ev ile iş arasında sıkışıp kalmaları (ne evden ne de işten vazgeçmek istemeleri) & 11 & 1,7 \\
\hline 25. İfade & Kadınların emir verildiğinde/ses tonu yükseldiğinde bozulmaları/yanlış anlamaları & 10 & 1,5 \\
\hline 26. İfade & Kadınların profesyonel mutfaklardaki işleri kaliteli yapamamaları/becerememeleri & 10 & 1,5 \\
\hline 27. İfade & Kadınların regl dönemlerinde verimli çalışamamaları & 10 & 1,5 \\
\hline 28. İfade & Kadınların profesyonel mutfaklarda çalışmaya istekli olmamaları & 10 & 1,5 \\
\hline 29. İfade & Kadınların profesyonel mutfaklarda kendilerini yalnız hissetmeleri & 9 & 1,4 \\
\hline 30. İfade & Kadınların profesyonel mutfaklarda iş yapmamak için bahane üretmeleri/işten kaytarmaları & 9 & 1,4 \\
\hline 31. İfade & Kadınların aşçılığı bir meslek olarak görmemeleri/benimsememeleri nedeniyle sadece para için çalışmaları & 8 & 1,2 \\
\hline 32. İfade & $\begin{array}{l}\text { Kadınların izin günlerini eşlerine göre ayarlamak istemeleri nedeniyle izin günlerinin belirlenmesi } \\
\text { konusunda sıkıntı yaşatmaları }\end{array}$ & 6 & 0,9 \\
\hline 33. İfade & Kadınların profesyonel mutfaklarda erkek çalışanlara soğuk/ön yargılı davranmaları & 5 & 0,7 \\
\hline 34. İfade & Kadınların profesyonel mutfaklarda diğer çalışanlarla sorun (dedikodu, çekememezlik gibi) yaşamaları & 5 & 0,7 \\
\hline 35. İfade & Kadınların profesyonel mutfaklarda kendilerini ispatlayamamaları nedeniyle geri planda kalmaları & 5 & 0,7 \\
\hline 36. İfade & $\begin{array}{l}\text { Kadınların profesyonel mutfaklarla ilgili hedeflerinin olmaması dolayısıyla yükselmek için çaba } \\
\text { göstermemeleri }\end{array}$ & 5 & 0,7 \\
\hline 37. İfade & Kadınların profesyonel mutfaklarda daha fazla iş kazası yapmaları (ellerini kesmeleri/yakmaları) & 4 & 0,6 \\
\hline 38. İfade & Kadınların profesyonel mutfaklarda sakar olmaları (bir şeyleri kırıp dökmeleri) & 3 & 0,4 \\
\hline 39. İfade & Kadınların talepleri yerine getirilmediğinde surat/naz yapmaları & 3 & 0,4 \\
\hline 40. İfade & Kadınların profesyonel mutfaklarda özgüvenli olmamaları & 2 & 0,3 \\
\hline 41. İfade & Kadınların çabuk hasta olmaları ve hastayken çalışamamaları & 2 & 0,3 \\
\hline 42. İfade & Kadınların profesyonel mutfaklardaki sıcaklığa dirençli/dayanıklı olamamaları & 1 & 0,2 \\
\hline
\end{tabular}


Bir sonraki aşamada kod tablosundan (Tablo 2) yararlanılarak tema tablosu (Tablo 3) oluşturulmuştur. Tablo 3' te benzer kodlar bir araya getirilerek, kadınların otellerdeki profesyonel mutfaklarda "istihdam edilmeme/sayıca az olma" nedenleri temalaştırılmış ve temalar, içerdiği kodlardan hareketle isimlendirilmiştir. "Çalıştığınız otelin mutfak bölümünde istihdam edilen kadınların az/çok sayıda olmasının nedenleri nelerdir?" şeklindeki dördüncü araştırma sorusunun cevabı verilirken; Tablo 2'de ve 3'te raporlanan bulgular tekrara düşmemek açısından eş zamanlı tartışılmaktadır. Toplumsal cinsiyet rollerinin kültürden kültüre farklılık gösterebilen özellikte olması nedeniyle tartışma, Türkçe literatürden hareketle yürütülmektedir.

Tablo 3: Erkek Aşçıbaşılar Açısından Otellerdeki Profesyonel Mutfaklarda Az Sayıda Kadın İstihdam Edilmesinin Nedenleri (İçerik Analizi Tema Tablosu)

\begin{tabular}{|c|c|c|c|c|c|}
\hline OLUMSUZ DÜŞÜNCELER & KULLANILAN İFADELER & $\sum \mathbf{i}$ & $\begin{array}{l}\sum_{\mathrm{i}} \\
(665)\end{array}$ & $\%$ & $\begin{array}{l}\% \\
(100,0)\end{array}$ \\
\hline \multirow{4}{*}{$\begin{array}{l}\text { (1) KADINLARIN PROFESYONEL } \\
\text { MUTFAKLARDAKİ İŞIN YAPISINA } \\
\text { UYGUN OLMAMASINDAN } \\
\text { KAYNAKLANAN SORUNLAR }\end{array}$} & $\begin{array}{l}\text { (1.1) Kadınların profesyonel mutfaklardaki } \\
\text { yoğun/hızlı/zor/yorucu/stresli çalışma temposuna dirençli/dayanıklı } \\
\text { olamamaları }\end{array}$ & 37 & \multirow{4}{*}{108} & 5,6 & \multirow{4}{*}{16,3} \\
\hline & $\begin{array}{l}\text { (1.2) Kadınların profesyonel mutfaklardaki uzun çalışma saatlerine } \\
\text { dirençli/dayanıklı olamamaları }\end{array}$ & 36 & & 5,4 & \\
\hline & $\begin{array}{l}\text { (1.3) Kadınların profesyonel mutfaklardaki her işi (ağır ve zahmetli } \\
\text { işler) yapamamaları }\end{array}$ & 34 & & 5,1 & \\
\hline & $\begin{array}{l}\text { (1.5) Kadınların profesyonel mutfaklardaki sıcaklığa } \\
\text { dirençli/dayanıklı olamamaları }\end{array}$ & 1 & & 0,2 & \\
\hline \multirow{6}{*}{$\begin{array}{l}\text { (2) KADINLARIN PROFESYONEL } \\
\text { MUTFAK TECRÜBELERININ } \\
\text { YETERSIZLIĞİNDEN } \\
\text { KAYNAKLANAN SORUNLAR }\end{array}$} & $\begin{array}{l}\text { (2.1) Kadınların profesyonel mutfak deneyimlerinin az olması/işi } \\
\text { bilmemeleri }\end{array}$ & 41 & \multirow{6}{*}{104} & 6,2 & \multirow{6}{*}{15,6} \\
\hline & $\begin{array}{l}\text { (2.2) Kadınların profesyonel mutfaklarda çıkan krizleri iyi } \\
\text { yönetememeleri }\end{array}$ & 24 & & 3,6 & \\
\hline & $\begin{array}{l}\text { (2.3) Kadınların profesyonel mutfaklarda karar verme/inisiyatif } \\
\text { kullanma konusunda pasif olmaları }\end{array}$ & 15 & & 2,3 & \\
\hline & $\begin{array}{l}\text { (2.4) Kadınlara profesyonel mutfaklardaki işlerin güvenle (göz } \\
\text { arkada kalmadan) teslim edilememesi }\end{array}$ & 12 & & 1,8 & \\
\hline & $\begin{array}{l}\text { (2.5) Kadınların profesyonel mutfaklardaki işleri kaliteli } \\
\text { yapamamaları/becerememeleri }\end{array}$ & 10 & & 1,5 & \\
\hline & (2.6) Kadınların profesyonel mutfaklarda özgüvenli olmamaları & 2 & & 0,3 & \\
\hline \multirow{4}{*}{$\begin{array}{l}\text { (3) TOPLUMSAL CINSIYYET } \\
\text { ROLLERINE BAĞLI MESAİ ve İZIN } \\
\text { SORUNLARI }\end{array}$} & $\begin{array}{l}\text { (3.1) Kadınların çeşitli bahanelerle (çocuğum/kocam hasta/misafir } \\
\text { gelecek/çocuğu okuldan almam gerekli/bakıcım izinli vb.) sürekli } \\
\text { izin istemeleri/işe gelmemeleri }\end{array}$ & 33 & \multirow{4}{*}{95} & 4,9 & \multirow{4}{*}{14,2} \\
\hline & (3.2) Kadınların fazla mesai yapmak istememeleri & 33 & & 4,9 & \\
\hline & $\begin{array}{l}\text { (3.3) Kadınların belirli saatlerde evde olmaları gerektiğinden } \\
\text { profesyonel mutfaklardaki mesai saatlerine/vardiya sistemine } \\
\text { uyamamaları }\end{array}$ & 23 & & 3,5 & \\
\hline & $\begin{array}{l}\text { (3.4) Kadınların izin günlerini eşlerine göre ayarlamak istemeleri } \\
\text { nedeniyle izin günlerinin belirlenmesi konusunda sıkıntı yaşatmaları }\end{array}$ & 6 & & 0,9 & \\
\hline \multirow{7}{*}{$\begin{array}{l}\text { (4) PROFESYONEL } \\
\text { MUTFAKLARDAKI ERKEK } \\
\text { EGEMEN ORTAMDAN } \\
\text { KAYNAKLANAN SORUNLAR }\end{array}$} & $\begin{array}{l}\text { (4.1) Kadınların profesyonel mutfak ortamına çabuk/kolay uyum } \\
\text { sağlayamamaları/yabancılık çekmeleri }\end{array}$ & 22 & \multirow{7}{*}{77} & 3,3 & \multirow{7}{*}{11,6} \\
\hline & $\begin{array}{l}\text { (4.2) Kadınların profesyonel mutfaklarda girişken } \\
\text { olamamaları/pasifize edilmeleri }\end{array}$ & 16 & & 2,4 & \\
\hline & $\begin{array}{l}\text { (4.3) Kadınların profesyonel mutfaklarda çalışan erkeklerle rahat } \\
\text { konuşamamaları/iletişim kurarken güçlük yaşamaları }\end{array}$ & 15 & & 2,3 & \\
\hline & $\begin{array}{l}\text { (4.4) Kadınların profesyonel mutfaklarda kendilerini yalnız } \\
\text { hissetmeleri }\end{array}$ & 9 & & 1,4 & \\
\hline & $\begin{array}{l}\text { (4.5) Kadınların profesyonel mutfaklarda kendilerini } \\
\text { ispatlayamamaları nedeniyle geri planda kalmaları }\end{array}$ & 5 & & 0,7 & \\
\hline & $\begin{array}{l}\text { (4.6) Kadınların profesyonel mutfaklarda erkek çalışanlara soğuk/ön } \\
\text { yargılı davranmaları }\end{array}$ & 5 & & 0,7 & \\
\hline & $\begin{array}{l}\text { (4.7) Kadınların profesyonel mutfaklarda diğer çalışanlarla sorun } \\
\text { (dedikodu, çekememezlik gibi) yaşamaları }\end{array}$ & 5 & & 0,7 & \\
\hline
\end{tabular}




\begin{tabular}{|c|c|c|c|c|c|}
\hline \multirow{8}{*}{$\begin{array}{l}\text { (5) KADINLARIN KARAKTER / } \\
\text { KİŞİLİK / DUYGUSAL vb. } \\
\text { ÖZELLİKLERINNDEN } \\
\text { KAYNAKLANAN SORUNLAR }\end{array}$} & $\begin{array}{l}\text { (5.1) Kadınların çok çabuk } \\
\text { alınmaları/bozulmaları/ağlamaları/küsmeleri }\end{array}$ & 19 & \multirow{8}{*}{77} & 2,9 & \multirow{8}{*}{11,6} \\
\hline & $\begin{array}{l}\text { (5.2) Kadınların duygusal olarak çabuk etkilenmeleri ve bunu işe } \\
\text { yansıtmaları }\end{array}$ & 15 & & 2,3 & \\
\hline & $\begin{array}{l}\text { (5.3) Kadınların profesyonel mutfaklardaki işin zorluğu/yoruculuğu } \\
\text { konusunda sürekli şikâyet etmeleri }\end{array}$ & 14 & & 2,1 & \\
\hline & $\begin{array}{l}\text { (5.4) Kadınların emir verildiğinde/ses tonu yükseldiğinde } \\
\text { bozulmaları/yanlış anlamaları }\end{array}$ & 10 & & 1,5 & \\
\hline & $\begin{array}{l}\text { (5.5) Kadınların profesyonel mutfaklarda iş yapmamak için bahane } \\
\text { üretmeleri/işten kaytarmaları }\end{array}$ & 9 & & 1,4 & \\
\hline & $\begin{array}{l}\text { (5.6) Kadınların profesyonel mutfaklarda daha fazla iş kazası } \\
\text { yapmaları (ellerini kesmeleri/yakmaları) }\end{array}$ & 4 & & 0,6 & \\
\hline & $\begin{array}{l}\text { (5.7) Kadınların profesyonel mutfaklarda sakar olmaları (bir şeyleri } \\
\text { kırıp dökmeleri) }\end{array}$ & 3 & & 0,4 & \\
\hline & $\begin{array}{l}\text { (5.8) Kadınların talepleri yerine getirilmediğinde surat/naz } \\
\text { yapmaları }\end{array}$ & 3 & & 0,4 & \\
\hline \multirow{4}{*}{$\begin{array}{l}\text { (6) KADINLARA YÜKLENEN } \\
\text { TOPLUMSAL CINSIYYET } \\
\text { ROLLERINDEN KAYNAKLANAN } \\
\text { SORUNLAR }\end{array}$} & $\begin{array}{l}\text { (6.1) Kadınların çeşitli nedenlerle (evlenme/gebelik/çocuk sahibi } \\
\text { olma/eşin veya ebeveynlerin çalışmalarına izin vermemesi vb.) işi } \\
\text { bırakmaları }\end{array}$ & 26 & \multirow{4}{*}{67} & 3,9 & \multirow{4}{*}{10,1} \\
\hline & $\begin{array}{l}\text { (6.2) Kadınların evlerinde de sorumlulukları olduğu için sürekli } \\
\text { yorgun olmaları ve performanslarının düşmesi/çabuk yorulmaları }\end{array}$ & 16 & & 2,4 & \\
\hline & $\begin{array}{l}\text { (6.3) Kadınların evlenmesi/çocuk sahibi olması/ eşin veya } \\
\text { ebeveynlerin çalışmalarına izin vermemesi gibi nedenlerle mesleğe } \\
\text { dair bir gelecek planlarının olmaması }\end{array}$ & 14 & & 2,1 & \\
\hline & $\begin{array}{l}\text { (6.4) Kadınların ev ile iş arasında sıkışıp kalmaları (ne evden ne de } \\
\text { işten vazgeçmek istemeleri) }\end{array}$ & 11 & & 1,7 & \\
\hline \multirow{3}{*}{$\begin{array}{l}\text { (7) KADINLARIN HENÜZ IŞ̧E } \\
\text { ALINMADAN KARŞILAŞTIKLARI } \\
\text { KARIYYER ENGELLERİ }\end{array}$} & $\begin{array}{l}\text { (7.1) Profesyonel mutfak çalışanlarının aşçıaşının kurduğu ekipten } \\
\text { oluşması ve ekip kurulurken kadınların tercih edilmemesi }\end{array}$ & 23 & \multirow{3}{*}{61} & 3,5 & \multirow{3}{*}{9,2} \\
\hline & $\begin{array}{l}\text { (7.2) Toplumsal/kültürel vb. anlamda profesyonel mutfakların kadın } \\
\text { istihdamına uygun olmaması }\end{array}$ & 20 & & 3,0 & \\
\hline & $\begin{array}{l}\text { (7.3) Kadınların profesyonel mutfaklardaki işleyişe uyum } \\
\text { sağlayamayacakları için tercih sebebi olmamaları }\end{array}$ & 18 & & 2,7 & \\
\hline \multirow{3}{*}{$\begin{array}{l}\text { (8) KADINLARIN FİZIKSEL } \\
\text { ÖZELLIKLERINDEN } \\
\text { KAYNAKLANAN SORUNLAR }\end{array}$} & $\begin{array}{l}\text { (8.1) Kadınların profesyonel mutfaklardaki ağır mutfak } \\
\text { ekipmanlarını kaldıramamaları/fiziksel anlamda zayıf olmaları }\end{array}$ & 41 & \multirow{3}{*}{53} & 6,2 & \multirow{3}{*}{8,0} \\
\hline & (8.2) Kadınların regl dönemlerinde verimli çalışamamaları & 10 & & 1,5 & \\
\hline & (8.3) Kadınların çabuk hasta olmaları ve hastayken çalışamamaları & 2 & & 0,3 & \\
\hline \multirow{3}{*}{$\begin{array}{l}\text { (9) KADINLARIN PROFESYONEL } \\
\text { MUTFAKLARLA İLGİLI KARIYER } \\
\text { HEDEFLERIN OLMAMASINDAN } \\
\text { KAYNAKLANAN SORUNLAR }\end{array}$} & $\begin{array}{l}\text { (9.1) Kadınların profesyonel mutfaklarda çalışmaya istekli } \\
\text { olmamaları }\end{array}$ & 10 & \multirow{3}{*}{23} & 1,5 & \multirow{3}{*}{3,4} \\
\hline & $\begin{array}{l}\text { (9.2) Kadınların aşçllı̆̆ } \text { bir meslek olarak } \\
\text { görmemeleri/benimsememeleri nedeniyle sadece para için } \\
\text { çalışmaları }\end{array}$ & 8 & & 1,2 & \\
\hline & $\begin{array}{l}\text { (9.3) Kadınların profesyonel mutfaklarla ilgili hedeflerinin olmaması } \\
\text { dolayısıyla yükselmek için çaba göstermemeleri }\end{array}$ & 5 & & 0,7 & \\
\hline
\end{tabular}

Araştırmaya katılmayı kabul eden 60 aşçıbaşının, otellerdeki profesyonel mutfaklarda az sayıda kadın istihdam edilmesinin nedenlerinin başında \%16,3 ile "kadınların profesyonel mutfaklardaki işin yapısına uygun olmaması" teması gelmektedir. Bu tema altında toplam 4 kod bulunmaktadır ve en çok tekrar edilen (37 tekrar, \%5,6) "kadınların profesyonel mutfaklardaki yoğun / hızlı / zor / yorucu / stresli çalışma temposuna dirençli / dayanıklı olamamaları" kodudur. Bu kodu "kadınların profesyonel mutfaklardaki uzun çalışma saatlerine dirençli/dayanıklı olamamaları" (36 tekrar, \%5,4) ve "kadınların profesyonel mutfaklardaki her işi (ağır ve zahmetli işler) yapamamaları" (34 tekrar, \%5,1) izlemektedir. "Kadınların profesyonel mutfaklardaki sıcaklığa dirençli/dayanıklı olamamaları" kodu ise (1 tekrar, \%0,2) sadece bir aşçıaşı tarafından ifade edilmiştir. Kodlar incelendiğinde, her birinin otellerdeki profesyonel mutfaklardaki işin yapısına dair olduğu görülmektedir. Araştırmaya katılan aşçıbaşılar, işin 
yapısına uygun olmamalarının kadınların mutfaklarda az sayıda olmasına neden olduğunu anlatırken aşağıdaki ifadeleri kullanmışlardır.

6 numaralı aşçıbaşı: "Erkeklerle yoğun çalışma temposunda, uzun çalışma saatlerinde sorun yaşamamaktayız. Kadınlar mutfakta sürekli şikâyetçi işin zorluğundan, yoruculuğundan, sıcak havalarda mutfak da sıcak bir yer olduğu için sıcaktan sürekli bir memnuniyetsiz halleri var."

47 numaralı aşçıbaşı: "Mutfak yoğunluğun ve stresin olduğu bir yer sürekli ayakta olman lazım, hızlı olman lazım, hep bir koşuşturma var kadın bu döngüyü kaldıramaz. Mutfak işin yoğunluğu gereği çok stresli bir yer ve kadınlar bu iş stresini kaldıramıyor"

İfadelerden de anlaşıldığı üzere aşçbaşılar, kadınların mutfaklardaki işin yapısına uygun olmadıklarını düşünmektedir. Bu düşüncenin, daha önceki bölümlerde mutfaklardaki kadın nüfusunun azlığına dair literatürden elde edilen istatistiklerle de desteklenerek, kalıplaşmış olduğu söylenebilir. Bununla birlikte Sezer ve Dönmez 'in (2016) yaptıkları çalışmada, 17 numaralı kadın aşçının "Zordur. Ama başarılmaz değildir. Hem mutfaktaki erkek güruhla savaşırsın hem kadın olmanın getirdiği zorluklarla. Yine de sevdiğin işi yapıyorsan tüm bunlara değer." ifadesi, kadınların mutfaklardaki işin, yapısı gereği zor olduğunu kabul ettiklerini ancak bu zorluğun mücadele edildiğinde aşılabileceğini göstermektedir.

Otellerdeki profesyonel mutfaklarda az sayıda kadın istihdam edilmesinin ikinci nedenini \%15,6 ile "kadınların profesyonel mutfak tecrübelerinin yetersizliği" teması oluşturmaktadır. Bu tema altında toplam 6 kod bulunmaktadır ve en çok tekrar edilen (41 tekrar, \%6,2) "kadınların profesyonel mutfak deneyimlerinin az olması/işi bilmemeleri" kodudur. Bu kodu "kadınların profesyonel mutfaklarda çıkan krizleri iyi yönetememeleri" (24 tekrar, \%3,6) ve "kadınların profesyonel mutfaklarda karar verme/inisiyatif kullanma konusunda pasif olmaları" (15 tekrar, $\% 2,3)$ izlemektedir. Bu temada en az tekrar eden kodlar ise "kadınlara profesyonel mutfaklardaki işlerin güvenle (göz arkada kalmadan) teslim edilememesi" (12 tekrar, \%1,8), "kadınların profesyonel mutfaklardaki işleri kaliteli yapamamaları/becerememeleri" (10 tekrar, \%1,5) ve "kadınların profesyonel mutfaklarda özgüvenli olmamaları" (2 tekrar, \%0,3) şeklinde sıralanmaktadır. Kodlar incelendiğinde, her birinin kadınların profesyonel mutfak tecrübelerinin yetersizliğine dair olduğu görülmektedir. Araştırmaya katılan aşçıbaşılar tecrübe yetersizliğinin mutfaklarda az sayıda kadın olmasına neden olduğunu anlatırken, aşağıdaki ifadeleri kullanmışlardır.

27 numaralı aşçıbaş: "İşin en önemli bölümünü erkek çalışanlar yapıyor, çünkü erkekler daha deneyimli yani aşçlarımız hep erkek olduğu için iş daha kolay ve sorunsuz ilerliyor"

31 numaralı aş̧̧ıaş: "Kadınlar otel mutfaklarında hem işgücü hem de işin kaliteli yapılması açısından yarar sağlamıyorlar."

Profesyonel mutfak tecrübelerinin yetersizliğinden kaynaklanan diğer sorunlar; kadınların krizleri iyi yönetememeleri, karar verme/inisiyatif kullanmada pasif kalmaları, işleri kaliteli yapmayı becerememeleri, özgüvenli olamamaları ve bunlar dolayısıyla aşçıbaşıların kadınlara güvenerek iş teslim edememeleridir. Dikkat edildiğinde bu sorunların deneyimle aşılabileceği görülmektedir. Deneyim kazanmanın yolu ise kadının kendisine yüklenen toplumsal cinsiyet rollerinden biraz olsun siyrılabilmesiyle mümkün görünmektedir.

Her ne kadar imkânsızmış gibi algılansa da günümüzde yaşanan değişimlerin de etkisiyle zaman içerisinde bu durumun aşlabileceği düşünülmektedir. Beidoğlu ve Batman'ın (2000) genç nesil ile yaptığı araştırma sonuçlarının, bu bağlamda umut verici olduğu söylenebilir. "Kadın meslek 
seçerken evine vakit ayırmayı düşünmemeli. Bu düşünce ile bence hiçbir mesleği yürütemeyiz. İnsanın kendi isteği olması gerekir. Eğer isteğin o doğrultudaysa ve onu yapacaksan ve kendini iyi hissedeceksen yani aileni biraz boşlayabilirsin." şeklindeki katılımcı ifadesi güzel bir örnek teşkil etmektedir. Araştırma sonuçları katılımcıların, kadınların meslek seçerken evlerine vakit ayırmayı dikkate alması gerekip gerekmediği noktasında, kadına eşit düzeyde eşitlikçi ve geleneksel roller yüklediklerini göstermektedir (Beidoğlu ve Batman, 2000:52).

Otellerdeki profesyonel mutfaklarda az sayıda kadın istihdam edilmesine üçüncü neden $\% 14,2$ ile "toplumsal cinsiyet rollerine bağlı mesai ve izin sorunları" temasıdır. Bu tema altında toplam 4 kod bulunmaktadır ve en çok tekrar edilen (33 tekrar, \%4,9) "kadınların çeşitli bahanelerle (çocuğum/kocam hasta/misafir gelecek/çocuğu okuldan almam gerekli/bakıcım izinli vb.) sürekli izin istemeleri/işe gelmemeleri" kodudur. Bu kodu "kadınların fazla mesai yapmak istememeleri" (33 tekrar, \%4,9) ve "kadınların belirli saatlerde evde olmaları gerektiğinden profesyonel mutfaklardaki mesai saatlerine/vardiya sistemine uyamamaları" (23 tekrar, \%3,5) izlemektedir. "Kadınların izin günlerini eşlerine göre ayarlamak istemeleri nedeniyle izin günlerinin belirlenmesi konusunda sıkıntı yaşatmaları" kodu ise (6 tekrar, \%0,9) bu tema içerisinde en az tekrar edilen kod olmuştur. Kodlar incelendiğinde, her birinin otellerdeki profesyonel mutfaklarda çalışan kadınların mesai ve izin konularıyla ilgili yaşadıkları/yaşattıkları sorunlara dair olduğu görülmektedir. Mesai ve izin konusuyla ilgili ortaya çıan sıkıntıların temelde kadına yüklenen toplumsal cinsiyet rolleriyle bağlantılı olduğu söylenebilir. Araştırmaya katılan aşçıbaşılar, kadınlarla yaşadıkları mesai ve izin sorunlarının profesyonel mutfaklarda kadın istihdamını olumsuz etkilediğini anlatırken aşağıdaki ifadeleri kullanmışlardır.

1 numaralı aşçıbaşı: "Kadınlar, sürekli bir sebepten dolayı izin istiyorlar. İşte çocuğum hasta, kocam hasta, kayınvalidemler gelecek gibi bir sürü sebepler oluyor ama erkeklerin bu tür sebeplerden dolayı izin istediğini görmedim en fazla banka için izin alırlar o da acele bir durum ise."

54 numaralı aşçıbaşı: "Bizim otelimiz vardiya sistemi ile çalışıyor ve kadınlar vardiya sistemine dâhil olmak istemiyorlar. Çünkü aileleri ve eşleri izin vermiyor geç saatlere kadar çalışmasına. Aslında iş en geç 23.00 'da bitmiş oluyor yani akşamdan sabaha kadar çalışmıyorlar. Ailelerinin izin vermemesinin yanında, kendileri de kalmak istemiyor. Çocukları var, akşam bakacak kimseleri yok, eşleri bakamıyor çocuğa, eşleri çocuklarıyla ilgilense yemeğini yediremez, yemeğini yedirse uyutamaz. Benim eşim çalı̧̧myor eğer çalışsa ben de yapamazdım, hak veriyorum aslında kadınlara ama sistemi değiştiremeyiz. Biz işe almadan önce vardiya sistemini anlatıyoruz kabul etmeyenleri almıyoruz işe ama bazen kabul eden arkadaşlarımızda ben bugün kalmayayım, erken çıkayım, misafirim gelecek gibi sorunlar oluyor."

Aşçıların ifadelerinden de anlaşılacağı üzere kadınların sıklıkla izin istemelerinin, mesaiye kalamamalarının, vardiya sistemine uyamamalarının ve izinlerini eşlerine göre ayarlamak istemelerinin temelinde keyfiyete bağlı bir durum bulunmamaktadır. Çünkü kadınlar, çalışsalar da çalışmasalar da ev içi sorumluluklarının ve çocuk bakımının çok büyük bir bölümünü üstlenmektedir. Benzer şekilde aile yapısı içerisinde kadının bekârken babanın, evlendiğinde de kocanın çizdiği sınırlar içerisinde kalması da bu sonuçların ortaya çıkışını beslemektedir.

Otellerdeki profesyonel mutfaklarda az sayıda kadın istihdam edilmesinin dördüncü nedeni ise $\% 11,6$ ile "profesyonel mutfaklardaki erkek egemen ortam" temasıdır. Bu tema altında toplam 7 kod bulunmaktadır ve en çok tekrar edilen (22 tekrar, \%3,3) "kadınların profesyonel mutfak ortamına çabuk/kolay uyum sağlayamamaları/yabancilık çekmeleri" kodudur. Bu kodu "kadınların profesyonel mutfaklarda girişken olamamaları/pasifize edilmeleri" (16 tekrar, \%2,4) ve "kadınların profesyonel mutfaklarda çalışan erkeklerle rahat konuşamamaları/iletişim kurarken güçlük yaşamaları" (15 tekrar, \%2,3) izlemektedir. Bu temada en az tekrar eden kodlar 
ise "kadınların profesyonel mutfaklarda kendilerini yalnız hissetmeleri" (9 tekrar, \%1,4), "kadınların profesyonel mutfaklarda kendilerini ispatlayamamaları nedeniyle geri planda kalmaları" (5 tekrar, \%0,7), "kadınların profesyonel mutfaklarda erkek çalışanlara soğuk/ön yargılı davranmaları" (5 tekrar, \%0,7) ve "kadınların profesyonel mutfaklarda diğer çalışanlarla sorun (dedikodu, çekememezlik gibi) yaşamaları" (5 tekrar, \%0,7) şeklinde sıralanmaktadır. Kodlar incelendiğinde, her birinin profesyonel mutfaklardaki erkek egemen ortamın sonuçlarına dair olduğu görülmektedir. Araştırmaya katılan aşçıbaşılar erkek egemen mutfak ortamının kadın istihdamını olumsuz etkileyen bir başka neden olduğunu anlatırken, aşağıdaki ifadeleri kullanmışlardır.

22 numaralı aşçıbaşı: “Uyum sürecinde bizim mutfă̆ımızda kadın çalışan çok olmadığı için bizim aramızda biraz yabancllık çekiyorlar."

12 numaralı aş̧̧ıaş: "Kadınlar biraz geri planda kalıyorlar bu konuda çok girişken olamıyorlar çünkü erkekler daha fazla mutfakta. Erkekler bu konu da daha çok söz sahibiler, yönetim ve insanları yönlendirme erkeklerin elinde."

51 numaralı aşçıbaşı: "Daha önce bir tane gerçekten işe ihtiyacı olduğu için bayan almıştık, o da bir ay anca dayand, on tane erkeğin arasında rahat edemedi, kendini biraz yalnız hissetti, konuşacak kimse yok, erkeklerle muhabbet kursa yanlış anlaşılacak, bizim için sıkıntı yoktu ama bir süre sonra işi bıraktı."

Otellerdeki profesyonel mutfaklarda hâkim olan erkek egemen ortamın kadın çalışanların iletişim kurma ve uyum sağlama süreçlerini olumsuz etkilediği, onları geri planda bıraktığ görülmektedir. Buna karşılık aşçıbaşıların görece basit bir çözüm ürettikleri söylenebilir: kadın istihdamını azaltmak...

Otellerdeki profesyonel mutfaklarda kadın istihdamının az sayıda olma nedenlerinin beşincisi, dördüncü tema olan "profesyonel mutfaklardaki erkek egemen ortam" ile aynı oranda $(\% 11,6)$ etkili görülen "kadınların karakter / kişilik / duygusal vb. özellikleri" temasıdır. Bu tema altında toplam 8 kod bulunmaktadır ve en çok tekrar edilen (19 tekrar, \%2,9) "Kadınların çok çabuk alınmaları/bozulmaları/ağlamaları/küsmeleri" kodudur. Bu kodu "kadınların duygusal olarak çabuk etkilenmeleri ve bunu işe yansıtmaları" (15 tekrar, \%2,3), "kadınların profesyonel mutfaklardaki işin zorluğu/yoruculuğu konusunda sürekli şikâyet etmeleri" (14 tekrar, \%2,1), "kadınların emir verildiğinde/ses tonu yükseldiğinde bozulmaları/yanlış anlamaları" (10 tekrar, $\% 1,5)$ ve "kadınların profesyonel mutfaklarda iş yapmamak için bahane üretmeleri/işten kaytarmaları" (9 tekrar, \%1,4) izlemektedir. Bu temada en az tekrar eden kodlar ise, "kadınların profesyonel mutfaklarda daha fazla iş kazası yapmaları (ellerini kesmeleri/yakmaları)" (4 tekrar, $\% 0,6)$, "kadınların profesyonel mutfaklarda sakar olmaları (bir şeyleri kırıp dökmeleri)" (3 tekrar, $\% 0,4)$ ve "kadınların talepleri yerine getirilmediğinde surat/naz yapmaları" (3 tekrar, \%0,4) şeklinde sıralanmaktadır. İlk bakışta iş kazası ve sakarlık ile ilgili kodlar bu temaya uygun değilmiş gibi görünmektedir. Ancak bu konulara dikkat çeken aşçıbaşıların kullandıkları ifadelerden, iş kazası ve sakarlık ile ilgili durumları, kadınların duygusallığına ve/veya dikkatsizliğine bağladıkları anlaşılmaktadır. Dolayısıyla temayı oluşturan toplam sekiz kodun da kadınların karakter / kişilik / duygusal vb. özellikleri ile ilgili olduğu görülmektedir. Araştırmaya katılan aş̧̧ıbşılar kadınlara dair bu özelliklerin profesyonel mutfaklardaki kadın istihdamını olumsuz etkileyen nedenler arasında olduğunu anlatırken, aşağıdaki ifadeleri kullanmışlardır.

17 numaralı aşçıbaş1: “Öncelikle çok alınganlar, mutfakta iş stresli, yoğun o yoğunlukta mesela ben Ali ustaya bağırıyorum, o işin yapımında kadınlar da yardım ettiyse onlar kendi üzerine alını küsüyorlar. Özellikle bu alınma, küsme ve ağlama durumları benim sabır sınırlarımı zorluyor." 
18 numaralı aş̧̧başı: "Kadınlar çok çabuk alınıyorlar, mesela geçenlerde bir kadın arkadaşımız birisiyle tartıştı ve hemen işi bırakmak istediğini söyledi yani bırakmanın en kolay yol olduğunu anlattık ama duygusal varlıklar olduğu için kırılgan oluyorlar ve bu hemen işe yansıyor."

19 numaralı aşçıbaş1: "Kadınlar mesela hastayken izin istiyorlar eğer izin verilmezse mutfakta nazlarından yanlarından geçilmiyor,"

Genel olarak aşçıbaşılar, kadınların; alınganlığı, duygusallığı, küsme huyu, ağlamaları üzerine yaşanan sorunlarla ilgili ifadeler kullanmaktadır. Ancak bahsi geçen tüm bu özelliklerin "insana dair" özellikler olduğunun unutulmaması gerekmektedir. "Kadınlar böyledir", "kadınlar şöyledir" gibi kalıp yargıların, profesyonel mutfaklardaki kadın istihdamını olumsuz etkilememesi gerektiği düşünülmektedir. Bununla birlikte, 2016 yılında istatistikler Türkiye'de çeşitli iş kollarında toplam 8.312 .000 (\%31) kadının istihdam edildiğini göstermektedir (www.tuik.gov.tr). Kadınları istihdam eden diğer iş kollarında da bu tür duygu durumlarının kadınlar için bir engel oluşturup oluşturmadığının da araştırılması gerekmektedir. Öte yandan; kadınların, profesyonel mutfaklarda karşılaştıkları ne tür olay ve yaklaşımların bu duygusallığa sebebiyet verdiğinin, kadın bakışıla değerlendirilmesi de aşçıbaşıların ifadelerinin altında yatan temel nedenlerin daha iyi anlaşılabilmesi açısından önerilmektedir.

Otellerdeki profesyonel mutfaklarda az sayıda kadın istihdam edilmesine altıncı neden $\% 10,1$ ile "kadınlara yüklenen toplumsal cinsiyet rollerinden kaynaklanan sorunlar" temasıdır. Bu tema altında toplam 4 kod bulunmaktadır ve en çok tekrar edilen (26 tekrar, \%3,9) "kadınların çeşitli nedenlerle (evlenme/gebelik/çocuk sahibi olma/eşin veya ebeveynlerin çalışmalarına izin vermemesi vb.) işi bırakmaları" kodudur. Bu kodu "kadınların evlerinde de sorumlulukları olduğu için sürekli yorgun olmaları ve performanslarının düşmesi/çabuk yorulmaları" (16 tekrar, $\% 2,4$ ) ve "kadınların evlenmesi/çocuk sahibi olması/ eşin veya ebeveynlerin çalışmalarına izin vermemesi gibi nedenlerle mesleğe dair bir gelecek planlarının olmaması" (14 tekrar, \%2,1) izlemektedir. "Kadınların ev ile iş arasında sıkışıp kalmaları (ne evden ne de işten vazgeçmek istemeleri)" kodu ise (11 tekrar, \%1,7) bu tema içerisinde en az tekrar edilen kod olmuştur. Kodlar incelendiğinde, her birinin otellerdeki profesyonel mutfaklarda çalışan kadınlara yüklenen toplumsal cinsiyet rollerinden kaynaklanan genel sorunlara dair olduğu görülmektedir. Araştırmaya katılan aşçıbaşılar, kadınlara yüklenen toplumsal cinsiyet rollerinin profesyonel mutfaklarda az sayıda kadın istihdam edilmesine yol açtığını anlatırken aşağıdaki ifadeleri kullanmışlardır.

23 numaralı aşçbaşı: "Mesela geçen sene soğukta ve kahvaltıda çalışan 2 kızımız evlendi, birisinin eşi mutfağa geldi gezdi, çok erkek çalışıyor diye artık çalışmasına izin vermedi kız işi bıraktı; diğeri evlenince başka bir şehre taşındı o da bıraktı kadınlarla bi ekip kurmak çok zor sizi birçok sebepten dolayı yarı yolda burakabilir."

43 numaralı aşçıbaşı: "Çünkü kadınlar bu mesleği ne kadar isterlerse istesinler erkekler kadar aktif olamıyorlar. Aile sorumluluğu var çocuk sorumluluğu var ev sorumluluğu var hepsi birden olunca çabuk yoruluyorlar."

Aşçıbaşıların ifadelerinden de anlaşılacağı gibi soyun devamı için bir zorunluluk olan doğurganlık, çalışma yaşamında kadınların dezavantajı haline dönüşmektedir. Yasal olarak gebelik öncesi ve sonrası kadınlara verilen doğum izinleri, aşçıbaşılar nezdinde iş gücü kaybı olarak değerlendirilmektedir. Bununla birlikte ataerkil toplumlarda toplumsal cinsiyet rolleri nedeniyle kadının sorumluluğu doğurma ve emzirmeyle de bitmemektedir. Çocukların doğumundan itibaren neredeyse sorumluluklarının tamamı kadınlar tarafından üstlenilmektedir. Örneğin çocuk hasta olduğunda bakılması, okuldan alınması gerekiyorsa 
alınması, bakıcı bulunamıyorsa kadının izin alması veya işten ayrılması araştırma bulgularında aşçıbaşılar tarafından da sıklıkla dile getirilerek desteklenmektedir. Bununla birlikte kadınların evdeki işlerden de birinci derecede sorumlu oldukları görülmektedir. Yemek, temizlik, çamaşır, bulaşık, ütü vb. ev içi sorumluluklar, özellikle de evli ve çocuklu kadınlar için daha fazla yük olmaktadır. Evdeki sorumlulukların erkeklerle paylaşılamaması durumu; kadın, bir de emek yoğun bir işte çalışıyorsa, ona iki kat yorgunluk olarak geri dönmektedir. Bu durum çalışma yaşamında yine kadın için dezavantaja dönüşmektedir.

Otellerdeki profesyonel mutfaklarda az sayıda kadın istihdam edilmesinin yedinci nedeninin \%9,2 ile "kadınların henüz işe alınmadan karşılaştıkları kariyer engelleri" teması olduğu görülmektedir. Bu tema altında toplam 3 kod bulunmaktadır ve en çok tekrar edilen (23 tekrar, \%3,5) "profesyonel mutfak çalışanlarının aş̧̧ıbaşının kurduğu ekipten oluşması ve ekip kurulurken kadınların tercih edilmemesi" kodudur. Bu kodu "toplumsal/kültürel vb. anlamda profesyonel mutfakların kadın istihdamına uygun olmaması" (20 tekrar, \%3,0) izlemektedir. "Kadınların profesyonel mutfaklardaki işleyişe uyum sağlayamayacakları için tercih sebebi olmamaları" kodu ise (18 tekrar, \%2,7) bu tema içerisinde en az tekrar edilen kod olmuştur. Kodlar incelendiğinde, her birinin kadınlara profesyonel mutfaklarda kendilerini göstermelerine dahi fırsat verilmeden karşı karşıya kaldıkları kariyer engellerine dair olduğu görülmektedir. Araştırmaya katılan aşçıbaşılar, kurdukları mutfak ekiplerinde kadınları neden daha az tercih ettiklerini anlatırken aşağıdaki ifadeleri kullanmışlardır.

17 numaralı aş̧̧ıbaşı: "Benim cinsiyet ayrımcılığı düşüncem tabi ki de yok kadınların mutfakta olmasını diğer çalışma alanlarında da olmasını ayaklarını üzerinde durmasını isterim ama kendilerine uygun olan işlerde çalışarak olmalı, mutfaklar kadınlar için uygun değil. Bu yüzden erkeklerle çalışmayı tercih ediyorum."

48 numaralı aşçıbaşı: "Genelde ekipte kadınları tercih etmeme nedenim hamile olmaları, anne olmaları ve eşleri, mutfaklar genel olarak özel sektörler arasında olduğu için işveren kendi cebini düşünüyor, kadınlar erkekler kadar tam zamanlı çalı̧̧amıyor işe kendilerini veremiyor böyle olunca erkek personelle çalışmayı tercih ediyorum."

31 numaralı aşçıbaş: "Otel mutfaklarında yemek yapmak evde iki tabak yemek yapmaya benzemez, ille de yemek yapmak istiyorsa evinde oturup çocuğuna eşine yemek yapsın. Kadınların dini olarak da çalışma hayatına girmelerinin doğru olduğunu düşünmüyorum."

Kadınlara dair aşçıbaşıların zihinlerindeki "kadınların profesyonel mutfaklardaki işleyişe uyum sağlayamayacakları" şeklindeki olumsuz bakış açısının, karşılaştıkları birkaç örneğin de negatif etkisiyle kalıplaşmış olduğu düşünülmektedir. Bu durumun mutfaklardaki kadın istihdamını henüz başlamadan bitirmesi; mesleğin, "erkek işi" olarak algılanmasının da önünü açmaktadır denilebilir. Kadınların iş yaşamının içindeyken karşılaşabileceği engellemeler ve maruz kalabileceği ayrımcllı̆ın yanında, profesyonel mutfaklarda baştan istihdam edilmelerinin önü kesilerek, kendilerini gösterme fırsatları da ellerinden alınıormuş gibi görünmektedir. Otellerdeki profesyonel mutfaklarda çalışan ekibin çekirdek üyelerinin genel anlamda aşçbaşılar tarafından oluşturulduğu bilinmektedir. Aşçıbaşıların, ifadeleriyle de destekledikleri, ekiplerini erkek üyelerden oluşturma tercihleri mesleki anlamda kadınları kısa vadede profesyonel mutfaklarda yükselmek bir yana yer bulmak açısından da karanlık bir senaryonun beklediği şeklinde yorumlanabilir. Bu noktada yükseköğrenimlerine aşçllık, gastronomi ve mutfak sanatları vb. bölümlerde devam eden kız öğrencilerin (örneğin sadece Mersin Üniversitesi Turizm Fakültesi bünyesindeki Gastronomi ve Mutfak Sanatları Bölümünde 43 kız öğrenci öğrenim görmektedir) profesyonel iş yaşamında kendilerine nasıl yer bulacaklarının araştırılması da gerekmektedir. Aşçılığı meslek edinmek maksadıyla bu alanda eğitim alan kız öğrencilerin, 
gelecekte profesyonel mutfaklarda; kahvaltı, pastane ve soğuk bölümünde çalışmakla yetinmeyecekleri düşünülmektedir.

Otellerdeki profesyonel mutfaklarda az sayıda kadın istihdam edilmesinin sekizinci nedenin $\% 8,0$ 'lik bir oranla "kadinların fiziksel özelliklerinden kaynaklanan sorunlar" teması olduğu görülmektedir. Bu tema altında toplam 3 kod bulunmaktadır ve en çok tekrar edilen (41 tekrar, $\% 6,2$ ) "kadınların profesyonel mutfaklardaki ağır mutfak ekipmanlarını kaldıramamaları/fiziksel anlamda zayıf olmaları" kodudur. Tema içerisinde en az tekrar edilen kodlar "kadınların regl dönemlerinde verimli çalışamamaları" (10 tekrar, \%1,5) ve "kadınların çabuk hasta olmaları ve hastayken çalışamamaları" (2 tekrar, \%0,3) şeklinde sıralanmaktadır. Kodlar incelendiğinde, her birinin kadınların fiziksel özelliklerinden kaynaklandığı görülmektedir. Araştırmaya katılan aş̧̧ıbaşılar, kadınların fiziksel özelliklerden kaynaklanan bu sorunların profesyonel mutfaklardaki kadın istihdamını neden olumsuz etkilediğini anlatırken aşağıdaki ifadeleri kullanmışlardır.

51 numaralı aşçıbaşı: "Kadınlar ağır eşyaları, malzemeleri kaldıramıyorlar, mutfakta sürekli tava, tencere, yemek malzemelerini kaldırmak zorundasını bunları yapamadıktan sonra yemek yapamazsinız zaten."

18 numaralı aşçıbaşı: "Erkeklere oranla daha çabuk hasta oluyorlar, kadınsal sorunları oluyor, erkekler hastayken çalışabiliyor ama kadınlarda bu dirayet olmuyor. Mesela ofiste 2 kişi gelmese belki çok sıkıntı olmaz ama mutfaklar organizasyon yapısı itibariyle insan gücüne dayalı yerlerdir."

Kadınların fiziksel anlamda erkeklerden görece daha zayıf olmaları, otellerdeki profesyonel mutfaklarda yer edinmelerinin önüne geçen önemli engellerden biri gibi görülmektedir. Sezer ve Dönmez 'in (2016) bulgularında, kadınlar tarafından da bu durum sıklıkla dile getirilmiştir. Kadın aşçılar fiziki anlamda erkeklerden daha zayıf olmalarını bir sorun olarak görmüştür ancak farklı özelliklerin ön plana çıkarılması ve kararlılıkla bu durumun üstesinden gelinebileceğini aşağıdaki ifadelerle aktarmışlardır.

"Mutfakta çalışmak mutlaka fiziksel güç gerektirir. Bu kaçınılmazdır. Ama ondan daha da önemli olan bir şey vardır ki o da zekâ. Ĕ̆ger zekânı güzel bir şekilde kullanıyorsan kadın olmanın öyle ahım şahım dezavantajı yoktur. Fiziksel güç olmadan yemek yapabilirsin ama zekâ olmadan salatalık bile doğrayamazsin."

Araştırmaya katılmayı kabul eden 60 aşçıbaşıdan, araştırma kapsamında elde edilen verilere göre otellerdeki profesyonel mutfaklarda az sayıda kadın istihdam edilmesinin sonuncu nedeni ise \%3,4'lük oranla "kadınların profesyonel mutfaklarla ilgili kariyer hedeflerinin olmaması" teması olmuştur. Bu tema altında toplam 3 kod bulunmaktadır ve en çok tekrar edilen (10 tekrar, $\% 1,5)$ "kadınların profesyonel mutfaklarda çalışmaya istekli olmamaları" kodudur. Bu kodu "kadınların aşçılığı bir meslek olarak görmemeleri/benimsememeleri nedeniyle sadece para için çalışmaları" (8 tekrar, \%1,2) izlemektedir. "Kadınların profesyonel mutfaklarla ilgili hedeflerinin olmaması dolayısıyla yükselmek için çaba göstermemeleri" kodu ise (5 tekrar, \%0,7) bu tema içerisinde en az tekrar edilen kod olmuştur. Kodlar incelendiğinde, her birinin kadınların profesyonel mutfaklarda uzun vadeli çalışma ve kariyer yapma hedeflerinin yetersizliğine dair olduğu görülmektedir. Araştırmaya katılan aşçıbaşılar, kadınların profesyonel mutfaklarda kariyer yapma konusunda herhangi bir planlama yapmadıklarını anlatırken aşağıdaki ifadeleri kullanmışlardır.

6 numaralı aşçıbaşı: "Kadınlar bu işi meslek olarak görmüyorlar genelde çalışanların paraya ihtiyacı olduğu için çalışıyor" 
7 numaralı aş̧̧ıbşı: "Kadınların mutfaklarda hedefleri yok, çalışma istekleri yok. Bunu bir meslek olarak görüp yükselmek için çaba sarf etmiyorlar, para kazanmak için bu işi yapıyorlar. Çünkü sürekli mutfaktan uzaklaşıyorlar, evleniyorlar, çocukları oluyor ya da eşleri izin vermiyor gibi birçok sorunları oluyor bu yüzden bir hedefleri olmuyor."

Profesyonel mutfaklarda kariyer hedefleyen kadınların sayıca artmakta olduğu, yükseköğretim seviyesinde mesleki eğitim veren bölümlerdeki kız öğrenci sayılarına bakılarak anlaşılabilir. Örneğin Mersin Üniversitesi, Turizm Fakültesi bünyesinde dört yıllık eğitim veren Gastronomi ve Mutfak Sanatları Bölümü'nde kayıtlı toplam 112 öğrencinin; 43'ü (\%38) kız öğrencidir. Bu durum, kadınların profesyonel mutfaklarda kariyer yapma hedeflerine, birikimlerini aldıkları yükseköğrenimle destekleyerek, daha sağlam adımlarla ilerledikleri şeklinde yorumlanabilir. Gelecekte yapılacak araştırma bulguları profesyonel mutfaklardaki kadın istihdamının değişip değişmediğinin, kadınların aşçıaşı statüsüne yükselip yükselemediğinin göstergesi olacaktır diye düşünülmektedir.

Veri analizleri sonucunda ise otellerdeki profesyonel mutfaklarda çalışan ve araştırmaya katılmayı kabul eden 60 aşçıbaşının tamamı (\%100) "erkek"tir. Sayfiye otellerindeki profesyonel mutfaklarda toplam 1.915 (\%82) iş gören istihdam edilirken; şehir otellerinde 429 (\%18) iş gören istihdam edilmektedir. Toplam istihdam içerisindeki kadın işgören oranı sayfiye otellerindeki profesyonel mutfaklarda \%13 iken; şehir otellerinde \%8'dir. Kadınlar, otellerdeki profesyonel mutfaklarda; en çok "kahvaltı" bölümünde çalıştırılmaktadır. Kahvaltı bölümünü "pastane" ve "soğuk" izlemektedir. "Sıcak" ise kadınların en az çalıştırıldıkları mutfak bölümü olmuştur.

\section{SONUÇLAR ve ÖNERİLER}

$\mathrm{Bu}$ çalışmada "kadınların otellerdeki profesyonel mutfaklarda istihdam edilme/edilmeme durumlarının ve nedenlerinin araştırılması" amaçlanmıştır. Araştırmanın amacı bağlamında, örnekleme dâhil edilen 60 aşçbaşıdan yarı yapılandırılmış görüşme tekniği ile nitel veri toplanmıştır. Kadınlar, otellerdeki profesyonel mutfaklarda en az çalıştırıldıkları mutfak bölümü ise "Sıcak" olmuştur. Sıcak mutfaklarda işlerin güç gerektirmesi ve zor olması nedeniyle kadın istihdamının bu bölümde az olduğu ifade edilmektedir. Kadın aşçllar ise fiziki gücün aşılamayacak bir problem olduğunu düşünmemektedir. Aşçıların genellikle mutfağın sıcak bölümünde yetişerek aşçbaşılığa yükseldiği bilgisinden hareketle otellerdeki profesyonel mutfaklarda çalışacak kadınların cam tavan engeliyle karşılaşma olasılıklarının bulunduğu söylenebilir. Otellerdeki profesyonel mutfaklarda az sayıda kadın istihdam edilmesinin nedenleri ise kadınların profesyonel mutfaklardaki işin yapısına uygun olmaması, kadınların profesyonel mutfak tecrübelerinin yetersizliği, toplumsal cinsiyet rollerine bağlı mesai ve izin sorunları, profesyonel mutfaklardaki erkek egemen ortam, kadınların karakter / kişilik / duygusal vb. özellikleri, kadınlara yüklenen toplumsal cinsiyet rolleri, kadınların henüz işe alınmadan karşılaştıkları kariyer engelleri, kadınların fiziksel özellikleri ve kadınların profesyonel mutfaklarla ilgili kariyer hedeflerin olmaması şeklinde sıralanmaktadır.

Kadınlar çalışma hayatının her bölümünde birçok zorluluklarla ve cinsiyet eşitsizliğiyle karşı karşıya kalmaktadır. Otel işletmelerinin mutfak bölümü de bu eşitsizliğin hüküm sürdüğü çalışma alanlarından bir tanesidir. Tüm çalışma hayatında olması gerektiği gibi profesyonel otel mutfaklarında da kadınların bilinçli zorluklarla karşı karşıya kalmadığı cinsiyet eşitliliğinin sağlandığı alanlar olmalıdır. Elde edilen verilerden hareketle araştırmanın uygulamaya yönelik birçok katkısının olduğundan bahsedilebilir. Çalışmaya katılan 60 aşçıbaşının ifadelerinden hareketle kadınların profesyonel mutfaklarda biraz daha özveri, gayret ve çaba göstererek $16,3^{\prime}$ lük olan kadınların profesyonel mutfakta işin yapısına uygun olmadığı temasına karşı önyargılar yıkılarak profesyonel mutfaklarda daha fazla kadın istihdamı sağlanabilecektir. Kadınların 
profesyonel mutfaklara kendilerini ait hissederek çalışmasıyla beraber bu mutfakları sahiplenmesi, çalışma hayatında oluşabilecek ilk sorunda işi bırakmak yerine biraz çabalayarak işine devam etmesi durumunda sektörde gelip-geçici personel niteliğinden kurtulabilir. Ayrıca kadınların çalışma hayatının tüm alanlarında varlığını koruyabilmesi adına toplumun kadına atfettiği toplumsal cinsiyet rollerinden sıyrılarak kendine çalışma hayatında yer bulmalıdır. Öte yandan otellerdeki profesyonel mutfaklarda istenilen kadın-erkek eşitliğinin pratikte sağlanamadı̆̆ı; üst düzey yöneticiler, insan kaynakları yöneticileri ve aşçıbaşılar tarafından her ne kadar biliniyor olsa da durumun teorik anlamda da altının çizilerek literatüre geçmesi ve bu eşitsiz ve ayrımcı ortamdan kaynaklanan sonuçların vardığı noktaların tartışma bölümünde aktarıldığı haliyle muhataplarına iletilmesi önemli görülmektedir. Bu şekilde konunun muhataplarının, kadın-erkek eşitliği bağlamında gerekli önlemleri almaya özendirilebileceğine inanılmaktadır. Yükseköğrenimlerine aşçılık, gastronomi ve mutfak sanatları vb. bölümlerde devam eden kız öğrencilerin erkek egemen profesyonel mutfaklarda kendilerine nasıl yer bulacaklarının ve kariyer basamaklarını tırmanacaklarının araştıılması da önem arz etmektedir. Gelecekte yapılacak araştırma bulgularının, profesyonel mutfaklardaki kadın istihdamının olumlu yönde değişip değişmediğinin ve kadınların, aşçıbaşı statüsüne yükselip yükselemediğinin göstergesi olacağı düşünülmektedir.

Araştırmalarda istenen ancak çeşitli nedenlerle giderilmesi mümkün olmayan bazı sınırlılıklar bulunabilmektedir. Bu araştırmanın; deneysel veya ilişkiselden ziyade keşifsel türde tasarlanması, verilerin yarı-yapılandırılmış mülakat tekniğiyle toplanması, elde edilen verilerin kişisel beyana dayalı olması, görüşmelerin belli bir zaman diliminde yapılması, nitel araştırmalar için kullanılan kartopu örnekleme yönteminin kullanılması, bulgularının otellerdeki profesyonel mutfakların dışındaki mutfaklara genellenememesi, aş̧̧ıbaşların görüşme sırasında etkilenebilecekleri çevresel faktörlerin kontrol edilememesi gibi sınırlılıklar bulgularını etkilemiş olabilir.

\section{KAYNAKÇA}

Bhasin K. (2003). Toplumsal cinsiyet "bize yüklenen roller". İstanbul: Kadınlarla Dayanışma Vakfı Yayınları.

Birdir, K., Derinalp, S. ve Çanakçı, T. (2013). Otel mutfaklarında çalışan iş görenlerin sorunları. 14. Ulusal Turizm Kongresi, Erciyes Üniversitesi 05-08 Aralık 2013. Kayseri. ss: 980-997.

Buz, S. (2009). Feminist sosyal hizmet uygulaması. Toplum ve Sosyal Hizmet Dergisi, 20(1): 53-65.

Çelik, M ve Şahin, S. A. (2018). İş Yaşamında Cinsiyet Ayrımcılığı: Kadın Aşçlar Örneği, Journal of Tourism and Gastronomy Studies 6(3): 370-383.

Cengiz, A. (2013). Kadın ruh sağh̆ğı ve toplumsal cinsiyet; Antalya ilinde bir klinikte uygulama. Yayımlanmamış Yüksek Lisans Tezi, Akdeniz Üniversitesi, Antalya.

Çınar, E. K. (2013). Ortaokul Türkçe ders kitaplarında toplumsal cinsiyet. Yayımlanmamış Yüksek Lisans Tezi, Pamukkale Üniversitesi, Denizli.

Dökmen, Z. Y. (2015). Toplumsal cinsiyet sosyal psikolojik açıklamalar. İstanbul: Remzi Kitabevi.

Ecevit, Y. (2003). Toplumsal Cinsiyetle Yoksulluk İlişkisi Nasıl Kurulabilir? Bu İlişki Nasıl Çalışılabilir? Cumhuriyet Üniversitesi Tıp Fakültesi Dergisi, 25(4): 86-88. 
Ersöz, A. G. (2015). Özel alan / kamusal alan dikotomisi: Kadınlığın "doğası" ve kamusal alandan dışlanmışlı̆̆ı. Sosyoloji Araştırmaları Dergisi, 18(1): 80-102.

Giritlioğu, İ. (2010). Otel mutfaklarında çalışan personelin sektörde kariyer düşüncelerinin ortaya konulmasına yönelik bir araştırma. Sosyal Gelişim Dergisi, 1(1): 111-124.

Gökhan, İ. (2010). Türkiye'deki feminist akımların modernite ve postmodernite ilişkilerine eleştirel bir bakış. Yayımlanmamış yüksek lisans tezi, İstanbul Üniversitesi, İstanbul.

Güleç, M. (2015). Kadın çalışanlarda cam tavan sendromunun örgütsel vatandaşlığa etkileri Kuşadası 4 ve 5 yıldızlı otel işletmelerinde bir uygulama. Yayımlanmamış Yüksek Lisans Tezi, Adnan Menderes Üniversitesi, Aydın.

http://www.tuik.gov.tr/PreTablo.do?alt_id=1068. [Erişim Tarihi: 17.03.2017].

http://www.tuik.gov.tr/PreIstatistikMeta.do;jsessionid...?istab_id=9030

[Erişim

Tarihi:26.10.2016].

http://www.tdk.gov.tr/index.php?option=com_bts\&arama=kelime\&guid=TDK.GTS.5971bbdb16 74e7.05537608 [Erişim Tarihi:11.02.2017]

Kalaycı, N., ve Hayırsever, F. (2014). Toplumsal cinsiyet eşitliği bağlamında vatandaşlık ve demokrasi eğitimi ders kitabına yönelik bir inceleme ve bu konuya ilişkin öğrenci algılarının belirlenmesi. Kuram ve Uygulamada Eğitim Bilimleri, 14(3): 1-26.

Kansu, A. (2015). Sağlık çalışanlarnna göre toplumsal cinsiyet (Nazilli devlet hastanesi örneği). Yayımlanmamış Yüksek Lisans Tezi, Beykent Üniversitesi, İstanbul.

Kaypak, Ş. (2014). Toplumsal cinsiyet bakış açısından kente bakmak. Niğde Üniversitesi İktisadi ve İdari Bilimler Fakültesi Dergisi, 7(1): 344-357.

Keskin, E. (2016). Beş faktör kişilik özellikleri ve cam tavan engeli arasındaki ilişkiler: Antalya Kundu bölgesindeki beş yıldızlı oteller üzerine bir uygulama. Yayımlanmamış Doktora Tezi, Süleyman Demirel Üniversitesi, Isparta.

Keskin, E. ve Kızılırmak, İ. (2020). Mutfak Departmanında Çalışan Kadınlar: Cinsiyet Ayrımcılığı Üzerine Bir Araştırma. Uluslararası Sosyal Araştırmalar 13(69): 1210-1218.

Kocacık, F., ve Gökkaya, V. B. (2005). Türkiye'de çalışan kadınlar ve sorunları. Cumhuriyet Üniversitesi İktisadi ve İdari Bilimler Dergisi, 6(1): 195- 219.

Kuzgun, Y., ve Sevim, S. A. (2004). Kadınların çalışmasına karşı tutum ve dini yönelim arasındaki ilişki. Ankara Üniversitesi Ĕ̆itim Bilimleri Fakültesi Dergisi, 37(1): 14-27.

Pekerşen, Y. (2015). Otel işletmelerinde çalışan aşçıların iş stres ile iş tatmini, örgütsel bağlllık ve toksik davranışları arasındaki ilişki. Yayımlanmamış Doktora Tezi, Mersin Üniversitesi, Mersin.

Samanlı, R. (2014). Çalışma hayatında cinsiyet- iletişim iliş̧isi. Yayımlanmamış Yüksek Lisans Tezi, Cumhuriyet Üniversitesi, Sivas. 
Sankır, H. (2010). Eril tahakküm ve üstün erillik olgusunun plâstik sanatlar alanında toplumsal cinsiyet rollerinin oluşumuna etkileri üzerine sosyolojik bir değerlendirme. Hacettepe Üniversitesi Sosyolojik Araştırmalar e- dergisi, 1-17.

Sezer G., ve Dönmez, B. (2016). Kadın aşçıların üzerine sinen patriyarka kokusu, 17. Ulusal Turizm Kongresi, Muğla Sıtkı Koçman Üniversitesi 20-23 Ekim 2016. Bodrum, Muğla. ss: 678- 688.

Taş, G. (2016). Feminizm üzerine genel bir değerlendirme: kavramsal analizi, tarihsel süreçleri ve dönüşümleri. Akademik Hasasiyetler, 3(5): 163-175.

Turan, N., Öztürk, A., Kaya, H., ve Aşt1, T. A. (2011). Toplumsal cinsiyet ve hemşirelik. Maltepe Üniversitesi Hemşirelik Bilim ve Sanatı Dergisi, 4(1): 167-173.

Tür, Ö., ve Koyuncu, Ç. A. (2010). Feminist uluslararası ilişkiler yaklaşımı: temelleri, gelişimi, katkı ve sorunları. Uluslararası İlişkiler Akademik Dergisi, 7(26): 3-24.

Türkoğlu, E. (2015). Uluslararası ilişkiler kuramında feminizm. Yayımlanmamış Yüksek Lisans Tezi, Selçuk Üniversitesi, Konya.

Üzel, E. (2006). Feminizm ve doğa ekseninde ekofeminizm. Yayımlanmamış Yüksek Lisans Tezi, Ankara Üniversitesi, Ankara.

Yıldırım, A. ve Şimşek, H. (2008). Sosyal bilimlerde nitel araştırma yöntemleri. Ankara: Seçkin Yayıncilik.

Yılmaz, D. V., Zeyneloğlu, S., Kocaöz, S., Kısa, S., Taşkın, L., Ve Eroğlu, K. (2009). Üniversite öğrencilerinin toplumsal cinsiyet rollerine ilişkin görüşleri. Uluslararası İnsan Bilimleri Dergisi, 6(1): 775-792.

Yılmaz, R. A. (2007). Reklamlarda toplumsal cinsiyet kavramı: 1960-1990 yılları arası Milliyet gazetesi reklamlarına yönelik içerik analizi. Selçuk Üniversitesi İletişim Fakültesi Akademik Dergisi, 4(4): 143-155.

Zeybekoğlu, Ö. (2009). Toplumsal cinsiyet bağlamında erkeklik olgusu. Yayımlanmamış Yüksek Lisans Tezi, Akdeniz Üniversitesi, Antalya. 